\title{
Altered cell cycle regulation in the lens of HPV-16 E6 or E7 transgenic mice: Implications for tumor suppressor gene function in development
}

\author{
Huichin Pan and Anne E. Griep ${ }^{1}$ \\ Department of Anatomy, University of Wisconsin Medical School, Madison, Wisconsin 53706 USA
}

\begin{abstract}
Tumor suppressor proteins are believed to play a role in regulating cell cycle control during mammalian development. The E6 and E7 oncoproteins from human papillomavirus type 16 are known to affect cell growth control, at least in part, through their inactivation of cellular tumor suppressor gene products, p53 and $\mathbf{R b}$, respectively. Therefore, these viral proteins can serve as trans-dominant repressors of tumor suppressor gene function. To study the potential role of p53 and $\mathrm{Rb}$ in murine lens morphogenesis, we generated transgenic mice in which the expression of $\mathrm{E} 6$ or $\mathrm{E} 7$ was directed to the developing lens. Transgenic mice expressing E7 exhibited microphthalmia and cataracts, whereas transgenic mice expressing E6 exhibited cataracts without noticeable microphthalmia. Microscopic analysis of the lenses from neonatal and adult E7 transgenic mice revealed inhibition of lens fiber cell differentiation, induction of cell proliferation in spatially inappropriate regions of the lens, and apoptosis. Transgenic mice expressing a mutant E7 that is defective in $\mathbf{R b} / \mathbf{p} 107$ binding exhibited normal eyes, suggesting that the activity of $\mathbf{R b}$ and/or $\mathbf{R b}$-like proteins is required for the perturbation of lens development and induction of apoptosis in E7 mice. Microscopic analysis of lenses from E6 neonatal and adult transgenic mice indicated the presence of nuclei in elongated fiber cells, suggesting that E6 inhibits lens fiber cell denucleation. Furthermore, expression of E6 inhibited the apoptotic-like DNA degradation observed in the lenses of nontransgenic 15.5-day embryos. In lenses from neonatal E6 $\times E 7$ double transgenic mice, the level of apoptosis was reduced compared with that seen in lenses from neonatal E7 mice. In adult E6 $\times$ E7 double transgenic mice, lens tumors developed, whereas in E6 or E7 only transgenic mice, tumors did not. Taken together, these results point to specific roles in lens morphogenesis for $\mathbf{R b}$ and $\mathrm{p} 53$ and to the necessity of these tumor suppressor gene products in regulating exit from the normal cell division cycle in differentiating lens fiber cells.
\end{abstract}

[Key Words: Development; tumor suppressor genes; papillomavirus oncogenes; apoptosis; lens; transgenic mice]

Received March 2, 1994; revised version accepted April 27, 1994.

Regulation of the cell division cycle is an essential process by which the cell monitors its growth and differentiation. During embryonic development, in a temporally and topographically controlled manner, a wide variety of cells exhibit the capacity to quiesce, to proliferate, to irreversibly withdraw from the cell cycle, or to undergo programmed cell death, resulting in their complete loss from the embryo. Not only must the entry of a cell from a quiescent to a proliferative phase be precisely regulated, but so must the transition of a cell to the terminally differentiated state and the maintenance of that terminally differentiated cell in the postmitotic state. The critical nature of cell cycle control in these processes in vivo can be recognized by observing the detri-

\footnotetext{
${ }^{1}$ Corresponding author.
}

mental consequence of deregulation-tumorigenesis. Although much progress has been made in identifying the molecular mechanisms of cell cycle control in vitro, mechanisms of control in vivo, particularly as they relate to the onset and perpetuation of the terminally differentiated state, are poorly understood. In our study we have addressed the hypothesis that the tumor suppressor gene products, $\mathrm{Rb}$ and $\mathrm{p} 53$, act as regulators of the cell cycle in vivo during lens development in the mouse.

From studies in vitro, the retinoblastoma susceptibility gene product $\mathrm{Rb}$ is known to play an important role in regulating cell growth and differentiation (Buchkovich et al. 1989; Chen et al. 1989; DeCaprio et al. 1989/. In its active hypophosphorylated state, $\mathrm{Rb}$ is a negative regulator of the cell cycle and functions during the $G_{1}$ phase by interacting with and blocking the activities of a family of transcription factors termed E2F /Chellappan et al. 
1991; Chittenden et al. 1991; Goodrich et al. 1991). Hyperphosphorylation of $\mathrm{Rb}$ by the cyclin-Cdk complexes at the $G_{1}-S$ transition inactivates $R b$, resulting in release of E2F, which in turn activates the expression of genes such as c-myc, N-myc, and DHFR (for review, see Nevins 1992) that promote cell proliferation by allowing cells to enter $\mathrm{S}$ phase. Recent studies in mice deficient for $\mathrm{Rb}$, generated by gene knockout experiments, have begun to identify the activities of $R b$ in vivo. These mice died by $\sim 13.5$ days of gestation and exhibited developmental defects in hematopoietic and nervous systems (Clarke et al. 1992; Jacks et al. 1992; Lee et al. 1992).

The p53 protein is thought to influence cell cycle control, at least in part, through its transcriptional transactivation capacities. A newly identified protein, variously termed WAF1 (El-Deiry et al. 1993), Cipl (Harper et al. 1993), p21 (Xiong et al. 1993), or Sdil (Noda et al. 1994), was identified as a p53 inducible protein that inhibits cyclin-Cdk complex kinase activity. Therefore, the function of $\mathrm{p} 53$ in $\mathrm{G}_{1}$ growth arrest may be explained by the induction of this protein, which inhibits $\mathrm{Cdk} \mathrm{ki-}$ nase activity, thus preventing the phosphorylation of critical cell cycle regulators such as $\mathrm{Rb}$ and blocking cell cycle progression. Such data suggest a link in the activities of $\mathrm{Rb}$ and $\mathrm{p} 53$ in cell cycle regulation. Curiously, results from $\mathrm{p} 53$ gene knockout studies indicate that $\mathrm{p} 53$ is not essential for normal development (Donehower et al. 1992).

The early lethality of the Rb-deficient embryos, although demonstrating that $\mathrm{Rb}$ plays an essential role in hematopoiesis and neurogenesis, precludes a comprehensive analysis of the scope of $\mathrm{Rb}$ function in vivo later in organogenesis. We have taken an alternative approach to study the function of $\mathrm{Rb}$ and other tumor suppressor gene products in development through the directed expression of trans-dominant repressors of tumor suppressor gene function to the ocular lens in transgenic mice.

Microscopic analysis of the rodent lens has provided a detailed cellular description of its development (McAvoy 1978). The adult lens is an organ composed of a large mass of differentiated epithelial cells, the fiber cells, bordered on its anterior surface by a single cell layer of undifferentiated cells, the epithelial cells. During lens development, in a process known as fiber cell differentiation, these undifferentiated epithelial cells acquire the capacity to divide, migrate, and differentiate, depending on their position in the lens with respect to other ocular tissues. During fiber cell differentiation, nuclei in the cells at the center of the lens gradually disappear (Kuwabara and Imaizumi 1974). From studies on lens development in the chick, fiber cell denucleation is known to entail the degradation of DNA into a series of fragments with discrete sizes (Appleby and Modak 1977), a profile similar to that exhibited by cells undergoing programmed cell death-apoptosis (Wyllie 1980). The result of this pattern of growth and differentiation is that the lens is organized into separate compartments of quiescent, proliferating, differentiating, and terminally differentiated cells. With this detailed blueprint of cell division and morphogenesis in the lens, the molecular mech- anisms that regulate this process can be studied. The histological profile of cell proliferation and denucleation make $\mathrm{Rb}$ and/or $\mathrm{Rb}$-like proteins and the $\mathrm{p} 53$ protein good candidates through which lens fiber cell differentiation may be regulated.

To determine whether $\mathrm{Rb}$ and/or $\mathrm{Rb}$-like proteins and p53 play a role in lens development, we have used the oncoproteins from the human papillomavirus as transdominant negative effectors of tumor suppressor gene function. It is well established that the oncoproteins from DNA tumor viruses, such as SV40, polyomavirus, adenovirus, and human papillomavirus, alter cellular growth and differentiation, at least in part, through their ability to bind to and inactivate cellular tumor suppressor gene products. The large T antigens (Tag) from SV40 (DeCaprio et al. 1988) and polyomavirus (Dyson et al. 1990) and the adenovirus E1A protein (AdE1A; Whyte et al. 1988) have been shown to bind to the Rb protein of human and mouse origin and to the $\mathrm{Rb}$-like proteins p107 and p130. The E7 protein from human papillomavirus type 16 (HPV-16) has also been shown to bind to human Rb (Dyson et al. 1989; Munger et al. 1989a) and to Rb-related proteins (Dyson et al. 1992; Davies et al. 1993). In mouse cells, a functional Rb-binding domain is required for E7 to induce DNA synthesis (Banks et al. 1990). The binding of these DNA tumor viral proteins to $\mathrm{Rb}$ disrupts the interaction between $\mathrm{Rb}$ and E2F /Chellappan et al. 1992), allowing E2F to then activate its downstream cellular target genes (for review, see Nevins 1992). The SV40 Tag (Lane and Crawford 1979; Linzer and Levine 1979), the adenovirus E1B 55-kD (AdE1B) protein (Sarnow et al. 1982), and the HPV-16 E6 protein (Werness et al. 1990) are capable of binding to p53 and, in so doing, disrupt p53 function (Yew and Berk 1992). Whereas the binding of SV40 Tag and AdE1B with p53 stabilizes p53, the interaction of E6 and p53 results in proteolytic degradation of p53 in human cells (Scheffner et al. 1990; Huibregtse et al. 1993). In mouse cells, inactivation, but not degradation, results from the E6-p53 interaction (Sedman et al. 1992) and E6 can substitute for p53 mutations in transformation assays in BMK cells (Storey and Banks 1993). Thus, the oncoproteins from the DNA tumor viruses can be considered to be transdominant negative effectors of tumor suppressor protein function.

Previously, we generated transgenic mice carrying a chimeric gene comprised of the murine $\alpha \mathrm{A}$-crystallin promoter fused to HPV-16 E6/E7 open reading frames (ORFs). Analysis of these mice indicated an efficient inhibition of lens cell differentiation and induction of proliferation and, in some cases, tumor formation after long latency (Griep et al. 1993). These properties were consistent with the previously ascribed capacities of E6/E7 in tissue culture to inhibit cell differentiation (Munger et al. 1989b; Hudson et al. 1990; Woodworth et al. 1990), to induce cell immortalization (Hawley-Nelson et al. 1989; Hudson et al. 1990; Woodworth et al. 1990), and to induce cell transformation in cooperation with other activated oncogenes (Matlashewski et al. 1987; Phelps et al. 1988; Storey et al. 1988). The lens phenotypes in these 
transgenic mice bore similarities with that seen when SV40 Tag and polyomavirus large $\mathrm{T}$ antigen (PyLT) were expressed in the developing lens (Mahon et al. 1987; Griep et al. 1989). This phenotype was, however, different from that generated by expression of polyomavirus middle $\mathrm{T}$ antigen (PyMT), which does not bind to $\mathrm{Rb}$ or p53, where lens fiber cell differentiation was not affected (A.E. Griep, unpubl.). The common phenotypes of SV40 Tag, HPV-16 E6/E7, and PyLT and the different phenotype of PyMT suggest that oncoproteins exert their effects on the lens through their dominant-negative interactions with p53 and $\mathrm{Rb}$. This mechanism would imply an essential role for these cellular genes in normal lens development.

To investigate this possibility, first we established that both $\mathrm{p} 53$ and $\mathrm{Rb}$ are expressed in the developing lens. Then we evaluated the individual activities of E6 and E7 in the lens by generating transgenic mice that express either E6 or E7 alone in the developing ocular lens. To investigate whether specific inactivation of $\mathrm{Rb}$ or Rb-like proteins is important in disrupting normal lens development, we also generated transgenic mice that express an E7 mutant protein that does not bind to $\mathrm{Rb}$. Results from this study indicate that E7 inhibits lens fiber cell differentiation and induces cell proliferation and apoptosis in spatially inappropriate regions of the lens, whereas E6 inhibits lens fiber cell denucleation and DNA degradation. Furthermore, the capacity of E7 to disrupt lens development and induce apoptosis is dependent on its ability to associate with $\mathrm{Rb}$ or Rb-like proteins. These data imply that $\mathrm{Rb}$ or Rb-like function is essential to maintain normal cell cycle control in terminally differentiating lens fiber cells and that the ultimate fate of these cells in the absence of $\mathrm{Rb}$ function is programmed cell death.

\section{Results}

\section{Expression of $R b$ and $p 53$ in the mouse lens}

Previous studies have indicated that the Rb gene is expressed in the mouse embryo as early as 9.5 days postcoitum (dpc), and in the adult mouse. Expression in individual tissues appears to be widespread yet to variable levels within both the embryo and adult (Bernards et al. 1989). Similarly, p53 expression is widespread during mouse embryogenesis and in adult tissues (Rogel et al. 1985; Schmid et al. 1991). To determine whether Rb and p53 also are expressed in the mouse ocular lens, RNA isolated from neonatal lenses was tested for $\mathrm{Rb}$ and $\mathrm{p} 53$ expression by RNA PCR, followed by Southern hybridization with $\mathrm{Rb}$ - and $\mathrm{p} 53$-specific probes. As shown in Figure 1, Rb and p53-specific RNA PCR fragments were detected in the mouse lens tissue, indicating that these genes are expressed in the lens. This result suggests that $\mathrm{Rb}$ and p53 may play a role in lens development. On the basis of this insight, we chose to monitor the effects on lens development of two papillomaviral oncogenes, HPV16 E6 and E7, known to possess, among other activities, the capacities to inhibit p53 and $\mathrm{Rb}$, respectively.
Probe:

$\mathbf{R b}$

p53

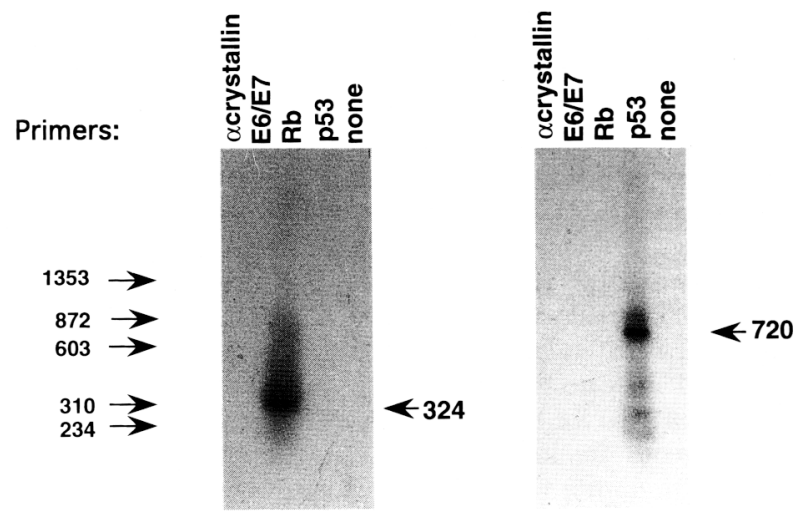

Figure 1. Expression of $\mathrm{Rb}$ and $\mathrm{p} 53$ in the mouse lens tissue. RNA isolated from lenses of neonatal FVB mice was reversetranscribed and subsequently PCR-amplified with various primers specific to the genes as indicated. Electrophoresed PCR products were subjected to Southern blot analysis using $\mathrm{Rb}$ - and p53-specific probes that detected the fragments of expected size of 324 and 720 bp for $R b$ and p53, respectively, when $R b$ and p53 primers were used. No hybridizing fragments were detected when primers for E6/E7 or $\alpha \mathrm{A}$ crystallin were used. The positions of size markers (HaeIII-digested $\phi X 174$ RF DNA) are indicated on the left margin.

\section{Production of E6 or E7 transgenic mice}

To express individually E6 or E7 in the developing lens, we generated two transgene DNAs, $\alpha$ AE6TTL/E7 and $\alpha$ AE6/E7TTL (Fig. 2). These DNAs are similar to the DNA, $\alpha \mathrm{AE} 6 / \mathrm{E} 7$, that we used previously for the generation of transgenic mice expressing both E6 and E7 /Griep et al. 1993) in that both the E6 and E7 translational ORFs are positioned in tandem behind the $\alpha \mathrm{A}$ crystallin promoter. They differ from $\alpha$ AE6/E7 in that a translational termination linker (TTL) has been placed into either the E6 or E7 ORF. The TTL is a 12-bp linker that contains translational termination codons in all ORFs (Phelps and Howley 1987). The HPV-16 E6/E7 regions of these plasmids were derived from the human $\beta$-actin expression plasmids, p1434 and p1436 (Munger et al. 1989b). The p1434 and p1436 have been characterized extensively and only the $\mathrm{E} 7$ protein is functionally expressed from p1434, whereas only the E6 proteins are functionally expressed from $\mathrm{p} 1436$. With these plasmids, no truncated proteins resulting from insertion of the TTL in the E7 ORF can be detected using immunological approaches that allow for detection of the full-length E7 protein nor has biological activity of the E6TTL or E7TTL mutant genes been detected in tissue culture assays in which the full-length E6 and E7 gene products display activities (K. Munger, pers. comm.). This failure to detect truncated proteins or biological activity for the predicted proteins may be attributable to the loss of the carboxy-terminal Cys- $X$ - $X$-Cys motif, thought to be important for the structural and functional integrity of E6 and E7 proteins, 
Figure 2. Diagram of the DNAs used for the generation of transgenic mice. The E6 and E7 ORFs were cloned between the murine $\alpha A$ crystallin promoter and SV40 polyadenylation sequences at the unique $\mathrm{BamHI}$ site (top line). The TTL was introduced in either E6 or E7 ORF to create $\alpha$ AE6TTL/E7 or $\alpha$ AE6/E7TTL, respectively. A deletion of amino acids 21-24, DLYC, was further introduced in the $\alpha$ AE6TTL/E7 backbone to create $\alpha$ AE6TTL/ $\mathrm{E} 7 \mathrm{Rb}^{-}$. The arrows labeled $\alpha \mathrm{cry} 3, \alpha \mathrm{pl}$, oligo 1, 2,3 , and 4 indicate the annealing positions of the primers used for PCR and RNA PCR along the transgene. The large arrow within the $\alpha A$ crystallin promoter represents the position of transcription initiation. The entire transcription unit of $1.45 \mathrm{~kb}$ was isolated by digestion with restriction enzymes XmaI and SalI, purified and microinjected as described in Materials and methods.

which is also considered to be an explanation for the failure to detect the putative $\mathrm{E} 6^{\star}$ and E6 * proteins. The use of the TTL to disrupt translation of one of the viral genes, rather than construction of transgenes in which the individual E6 or E7 ORF is placed downstream of the $\alpha \mathrm{A}$ crystallin promoter, preserved the tandem arrangement of the E6 and E7 genes as occurs naturally in the papillomaviral genome, which may contribute to efficient expression of both oncogenes in tissue culture cells (Munger et al. 1989b), as well as in transgenic mice (Griep et al. 1993, and unpubl.). Fragments of DNA containing these two transgenes were purified and subsequently microinjected into one-cell $\mathrm{FVB} / \mathrm{N}$ mouse embryos.

Transgenic mice were screened initially by PCR amplification using tail DNA as a template and the oligonucleotide primers $\alpha$ cry 3 and oligo 4 (Fig. 2). Southern blot analyses of tail DNA were performed subsequently to confirm the PCR results. The presence of the TTL in the transgene was documented by digesting the PCRgenerated DNA fragments with restriction enzyme $\mathrm{HpaI}$ that is present only within the TTL. The pattern of the digested bands on agarose gels indicated that all transgenic lines carried the expected transgene /data not shown).

\section{Lens phenotypes of the E6 or E7 transgenic mice}

Four transgenic founder animals, 75, 82, 83, and 908, were produced with the $\alpha$ AE6TTL/E7 transgene and were bred to establish independent lines (Table 1). All four $\alpha$ AE6TTL/E7 founder mice exhibited lens defects of bilateral microphthalmia and cataracts similar to those seen in $\alpha$ AE6/E7 mice, which express both E6 and E7. The phenotype was inherited with $100 \%$ penetrance in all $\alpha$ AE6TTL/E7 lines.

Three independent transgenic lines were produced
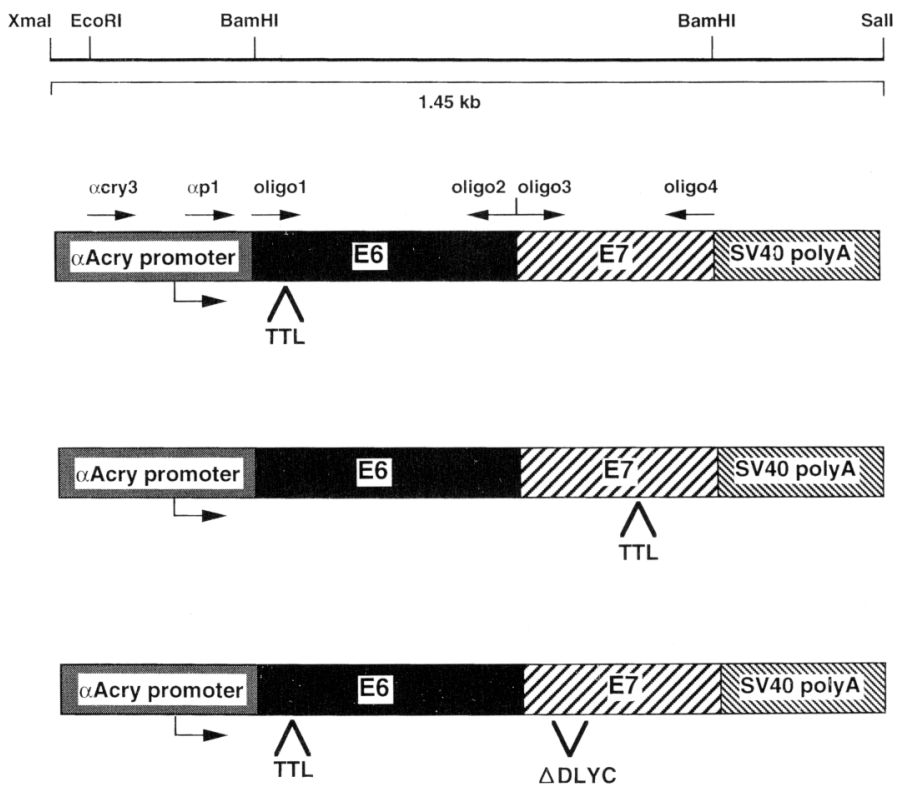

with the transgene $\alpha$ AE6/E7TTL, lines 371, 381, and 384. Mice in line 371 exhibited no overt lens phenotype. Although the majority of transgenic weanlings in lines 381 and 384 had cataractous eyes $184 \%$ and $74 \%$, respectively; see Table 1), the size of the eyes was similar to that of nontransgenic mice. This cataractous phenotype was unstable in line 381 mice; by the age of 10 months, only $47 \%$ ( 8 of 17 mice examined) of mice in line $381 \mathrm{had}$ cataractous eyes. The cataract defect was more stable in line $384 ; 89 \%$ (16 of 18 mice examined) of the mice had cataractous eyes at 10 months of age.

In our previous study we found that expression of both E6 and E7 led to the frequent occurrence of lens tumors in one line of aAE6/E7 transgenic mice /40\% in line 19 mice; Griep et al. 1993). In contrast, we did not detect any lens tumors in $\alpha$ AE6/E7TTL mice. Of the $\alpha$ AE6TTL/E7 mice, one mouse in line 908 that was homozygous for the transgene developed a lens tumor at 15 months of age; all other $\alpha$ AE6TTL/E7 mice examined were negative (Table 1). To assess whether E6 and E7 together can potentiate lens tumorigenesis, line $75 \mathrm{a}$ $\alpha$ AE6TTL/E7 and line 381a $\alpha$ AE6/E7TTL mice, both completely defective in lens tumorigenesis, were mated to generate double transgenic mice. Of 44 double transgenic mice, 7 developed lens tumors by 6-7 months of age. This suggests that, together, E6 and E7 can potentiate the lens for tumorigenesis, whereas neither E6 nor E7 alone has this capacity.

\section{Expression of the E6 and E7 transgenes in the lens}

To verify expression of the transgenes, RNA isolated from neonatal lenses of various lines was subjected to RNA PCR and Southern blot analysis. The RNA was first reverse-transcribed with oligo 2 or 4 , and the cDNA subsequently amplified with oligo $\alpha \mathrm{P} 1$ and oligo 2 and the PCR products then probed with an E6/E7-specific 
Table 1. Transgenic mice summary

\begin{tabular}{|c|c|c|c|c|c|c|}
\hline \multirow[b]{2}{*}{ Transgene } & \multirow{2}{*}{$\begin{array}{l}\text { Transgenic } \\
\text { lines }^{\mathrm{a}} \text { (no.) }\end{array}$} & \multicolumn{3}{|c|}{ Phenotype } & \multicolumn{2}{|c|}{ Transgene $^{b}$} \\
\hline & & microphthalmia & cataract & lens tumor ${ }^{c}$ & integration sites & copy number \\
\hline \multirow[t]{3}{*}{$\alpha \mathrm{AE} 6 / \mathrm{E}^{\mathrm{d}}$} & 4 & yes & yes & $0 / 40$ & 1 & 3 \\
\hline & 18 & yes & yes & $0 / 40$ & 1 & 3 \\
\hline & 19 & yes & yes & $19 / 41$ & 1 & 9 \\
\hline \multirow[t]{4}{*}{$\alpha$ AE6TTL/E7 } & $75(75 a ; 75 b ; 75 c)$ & yes & yes & $0 / 47,0 / 23,0 / 22$ & $3(1 ; 1 ; 1)$ & $4(2 ; 1 ; 1)$ \\
\hline & 82 & yes & yes & $0 / 24$ & 1 & 10 \\
\hline & 83 & yes & yes & $0 / 27$ & 1 & 14 \\
\hline & 908 & yes & yes & $1 / 26$ & 1 & 5 \\
\hline \multirow[t]{3}{*}{$\alpha$ AE6/E7TTL } & 371 & no & no & $0 / 19$ & 1 & 5 \\
\hline & 381 (381a) & no & yes $(21 / 25)^{e}$ & $0 / 21$ & $2(1)$ & $8(7)$ \\
\hline & 384 & no & yes $(20 / 27)^{e}$ & $0 / 26$ & complex ${ }^{f}$ & N.D. \\
\hline \multirow[t]{3}{*}{$\alpha \mathrm{AE} 6 \mathrm{TTL} / \mathrm{E} 7 \mathrm{Rb}^{-}$} & 391 (391a) & no & no & $0 / 7$ & $2(1)$ & $5(4)$ \\
\hline & 691 & no & no & - & 2 & 2 \\
\hline & 695 & no & no & - & 1 & 1 \\
\hline \multicolumn{7}{|l|}{$\alpha$ AE6TTL/E7 } \\
\hline$\times \alpha \mathrm{AE} 6 / \mathrm{E} 7 \mathrm{TTL}$ & $75 a \times 381 a$ & yes & yes & $7 / 44$ & & \\
\hline
\end{tabular}

(N.D.) Not determined.

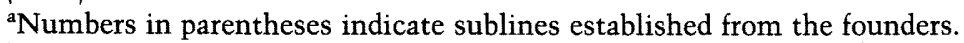

${ }^{b}$ Numbers in parentheses indicate integration sites and copy numbers for the corresponding sublines.

'Number of transgenic mice at 12-15 months of age that developed lens tumors. None of the animals in line 691 and 695 had reached this age, and only 7 mice in line 391 had reached this age. For line 19 homozygotes and the double transgenic mice, lens tumors were detected as early as 6 months of age.

${ }^{\mathrm{d}}$ For comparison, data taken from Griep et al. (1993).

eNumber of transgenic mice with cataracts at 1 month of age.

${ }^{\mathrm{f}}$ The genotype was complex by Southern analysis; however, all the progeny had the identical genotype as the founder.

probe (Fig. 3A). As diagramed in Figure 3A, three differentially spliced transcripts specific to E6/E7 sequences were predicted from the transgenes. Three amplification products were detected in lens RNA from all $\alpha$ AE6TTL/
E7 (Fig. 3B) and $\alpha$ AE6/E7TTL (Fig. 3C) transgenic lines, indicating that both E6- and E7-specific transcripts are present in the lens of $\alpha$ AE6TTL/E7 and $\alpha$ AE6/E7TTL mice. As stated above, the only proteins expected to ac-
A

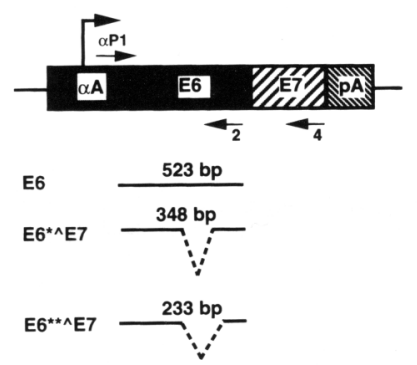

B

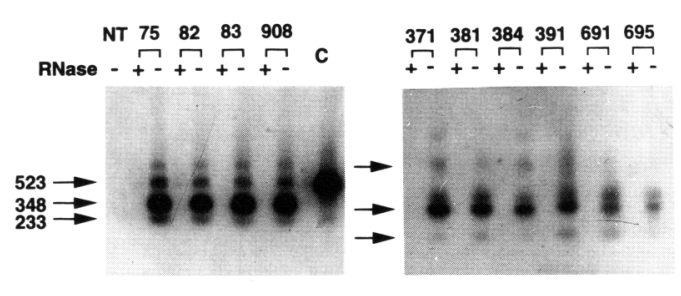

Figure 3. Expression of the transgenes in the lens. $(A \mid$ Diagram showing the strategy for RNA PCR and the sizes of the predicted products. (Top) ( $\alpha \mathrm{A})$ Murine $\alpha \mathrm{A}$ crystallin promoter unit; (E6 and E7) HPV-16 E6 and E7, respectively, ORFs; (pA, SV40) polyadenylation sequences. The arrows labeled $\alpha \mathrm{pl}, 2$, and 4 indicate the annealing positions of the primers used for RNA PCR along the transgene. The large arrow within the $\alpha \mathrm{A}$ crystallin promoter represents the position of transcription initiation. (Bottom) Predicted sizes for PCR products resulting from $\mathrm{E} 6(523 \mathrm{bp}), \mathrm{E} 6{ }^{\star \wedge} \mathrm{E} 7$ $\left(348 \mathrm{bp}\right.$ ), and E6 ${ }^{\star \star} \mathrm{E} 7(233 \mathrm{bp}$ ) messages when reverse transcription is performed with oligo 2 or oligo 4 and PCR with oligo $\alpha \mathrm{P} 1$ and oligo 2. Broken lines represent splicing within the E6 ORF, which gives rise to the E6 ${ }^{\star} \mathrm{E} 7$ and $\mathrm{E} 6^{\star \star}{ }^{\star} \mathrm{E} 7$ transcripts. The unspliced message gives rise to E6 protein, whereas both spliced messages give rise to E7 protein, which is translated from an ATG downstream of the $3^{\prime}$ splice site. The $\mathrm{E}^{\star}$ and $\mathrm{E} 6^{\star \star}$ proteins that can be predicted also to be derived from the spliced messages have never been identified. The TTL inserted in the E6 ORF is upstream of the $5^{\prime}$ splice site. The TTL inserted in the E7 ORF is $3^{\prime}$ of all splice signals and the ATG used for E7 translation. $(B)$ RNA PCR/Southern blot analysis of neonatal $\alpha$ AE6TTL/E7 lens RNA. RNA isolated from neonatal lenses from various $\alpha$ AE6TTL/E7 lines as indicated $(75,82,83,908)$ was reverse-transcribed with either oligo 2 or oligo 4 and PCR-amplified with oligo $\alpha \mathrm{Pl}$ and oligo 2 . The PCR products were separated on $2 \%$ agarose gels, transferred to nitrocellulose, and hybridized to $\left[\alpha^{-32} \mathrm{P}\right]$-labeled E6 and E7 DNA. Arrows at left indicate the positions of PCR-generated fragments from the unspliced $(523$ $\mathrm{bp}$ ) and spliced ( 348 and $233 \mathrm{bp}$ ) messages that hybridize to the E6/E7 probe. (C) RNA PCR/Southern blot hybridization analysis of neonatal $\alpha$ AE6/E7TTL and $\alpha$ AE6TTL/E7Rb ${ }^{-}$lens RNA. RNA isolated from neonatal lenses from various $\alpha$ AE6/E7TTL (371, 381, 384) and $\alpha$ AE6TTL/E7Rb- $(391,691,695)$ lines as indicated was analyzed as in B. Arrows at left indicate the positions of PCR-generated fragments from the unspliced ( $523 \mathrm{bp}$ ) and spliced ( 348 and $233 \mathrm{bp}$ ) messages that hybridize to the E6/E7 probe. (NT) Nontrangenic lens; (C) positive control for PCR, the plasmid paAHPV-16 E6/E7 (Griep et al. 1993); (+ and - / with or without RNase pretreatment before reverse transcription. 
cumulate stably in transgenic lens cells as a result of translation of these transcripts are full-length $\mathrm{E} 7$ protein in $\alpha$ AE6TTL/E7 lenses and full-length E6 protein in $\alpha$ AE6/E7TTL lenses. We have detected full-length E7 protein in lens extracts derived from mice in $\alpha$ AE6TTL/ E7 line 75 a by immunoprecipitation-immunoblotting protocols (data not shown). The level of E7 protein in this tissue was $\sim 250 \mathrm{pg} / \mathrm{mg}$ of total protein, which is similar, in our hands, to the level of E7 detected in the $\mathrm{HPV}-16^{+}$cervical carcinoma cell line $\mathrm{SiHa}$.

To be able to interpret accurately possible similarities and differences among the phenotypes of the $\alpha \mathrm{AE} 6 / \mathrm{E} 7$, the $\alpha$ AE6TTL/E7, the $\alpha$ AE6/E7TTL, and the $\alpha$ AE6TTL/ $\mathrm{E} 7 \mathrm{Rb}^{-}$lenses (see below), we wished to determine whether the levels of transgene message were comparable between these transgenic lines. Thus, quantitative RNA PCR was carried out on RNA from neonatal lenses (Griep et al. 1993). The level of transgene expression was similar among the $\alpha A E 6 T T L / E 7$ lines, and this range was comparable to that observed in lines 4 and $18 \alpha \mathrm{AE} 6 /$ E7 mice (Griep et al. 1993; Table 2; data not shown). The levels of transcripts were also comparable with that seen in the $\alpha$ AE6/E7TTL mice (see below and Table 2).

As described above, we observed some variation in the severity of phenotype among the different lines of the $\alpha$ AE6/E7TTL mice. By quantitative RNA PCR, a fivefold variation in the level of transgene-specific RNA was seen among the three E6-expressing lines (Table 2) and this was correlated with the severity of the lens phenotype in these $\alpha$ AE6/E7TTL mice. Line 371, which exhibited normal lenses expressed the lowest level of E6. Line 381a, which exhibited cataractous lenses early in adult life but less so later in adult life, expressed an intermediate level of E6. Line 384, which exhibited cataracts in the majority of mice both early and later in adult life, expressed the highest level of E6. Taken together, these data suggest that the severity of cataract formation in these E6-

Table 2. Quantitative RNA PCR analysis of transgenes in lens tissue

\begin{tabular}{lcc}
\hline Construct & Lineages & RNA copies/cell (mean \pm s.D.) \\
\hline$\alpha$ AE6TTL/E7 & $75 a$ & $72.3 \pm 13.9$ \\
& 82 & $112.7 \pm 41.3$ \\
& 83 & $430.0 \pm 147.9$ \\
$\alpha$ AE6/E7TTL & 908 & $123.3 \pm 65.5$ \\
& 371 & $94.7 \pm 30.2$ \\
& $381 \mathrm{a}$ & $344.7 \pm 86.76$ \\
$\alpha$ AE6TTL/E7Rb & 384 & $516.3 \pm 84.56$ \\
& $391 \mathrm{a}$ & $130.3 \pm 51.7$
\end{tabular}

Quantitative RNA PCR analysis was performed as described in Griep et al. (1993). In vitro-transcribed E7 RNA was quantitated by EtBr-stained gels and was used as standards in the experiments. Calculation of the number of copies of the viral RNAs per cell was derived from the equation $4 \times 10^{-11}$ grams of RNA per cell, assuming that one cell $=4 \times 10^{-9}$ grams and that RNA $=1 \%$ of cell mass. PCR mixtures were run in triplicate within an experiment; three independent experiments were performed and data averaged. expressing mice was correlated with the amount of E6 transcript present.

\section{Histological examination of the transgenic lenses}

To determine the cellular basis for the microphthalmia and cataract formation in the transgenic mice, eyes from neonatal and adult $\alpha$ AE6TTL/E7 and $\alpha$ AE6/E7TTL mice were prepared for histological analysis /see Materials and methods). The normal developmental program of the lens, consisting of primary and secondary fiber cell differentiation, occurs in two sequential stages. Fiber cell differentiation proceeds rapidly during the later stages of embryogenesis and in early postnatal life and continues, albeit at a diminished rate, as the animal ages. Primary fiber cell differentiation, which ultimately forms the nucleus (center) of the lens, occurs around days 11.5-13.5 of mouse embryogenesis. The cells in the posterior region of the lens vesicle become postmitotic and elongate toward the anterior surface, filling the vesicle. Secondary fiber cell differentiation, which forms the cortex (periphery) of the lens, begins at the conclusion of primary fiber cell differentiation. The germinal epithelial cells, located anterior to the equator of the lens vesicle, divide, move to the posterior toward the equator, elongate and move into the cortex as they differentiate into secondary fiber cells. Both primary and secondary fiber cell differentiation are characterized by loss of mitotic activity, cell elongation, and expression of differentiation-specific crystallin genes. Although the peripheral fiber cells have nuclei, the fiber cells in the center of the lens have lost their nuclei, as well as other cellular organelles, through an apoptotic-like process. This differentiation process results in a multilayered architecture, in which fiber cells make up the majority of the lens mass, bounded on the anterior surface by a single-cell layer of undifferentiated epithelium. These features are evident in histological sections of the lens from a nontransgenic FVB neonatal mouse (Fig. 4A).

The $\alpha A E 6 T T L / E 7$ lenses In contrast to the nontransgenic lens, the $\alpha$ AE6TTL/E7 lens from line 75a mice was disorganized and lacked fiber cell elongation. Numerous small, rounded, nucleated cells were found throughout the lens (Fig. 4C). The nontransgenic lens was devoid of mitotic cells within the posterior, posterior equatorial, and central regions of the lens (Fig. 4F). However, the E7-expressing lens contained mitotic cells in the posterior and posterior equatorial regions (Fig. 4E). Furthermore, the E7-expressing lens contained numerous pycnotic and fragmented nuclei, indicative of cell death, throughout the center (Fig. 4, cf. E and F). Histological examination of adult E7 transgenic lenses showed a small, misshapen structure with very few cells (Fig. 5B), which is consistent with the extremely small eyes observed in these mice. The histology of line $75 \mathrm{a}$ lenses was similar to that seen in lenses derived from mice of all $\alpha$ AE6TTL/E7 lines.

Further evidence for cell proliferation in spatially inappropriate regions of the lens was obtained by immu- 

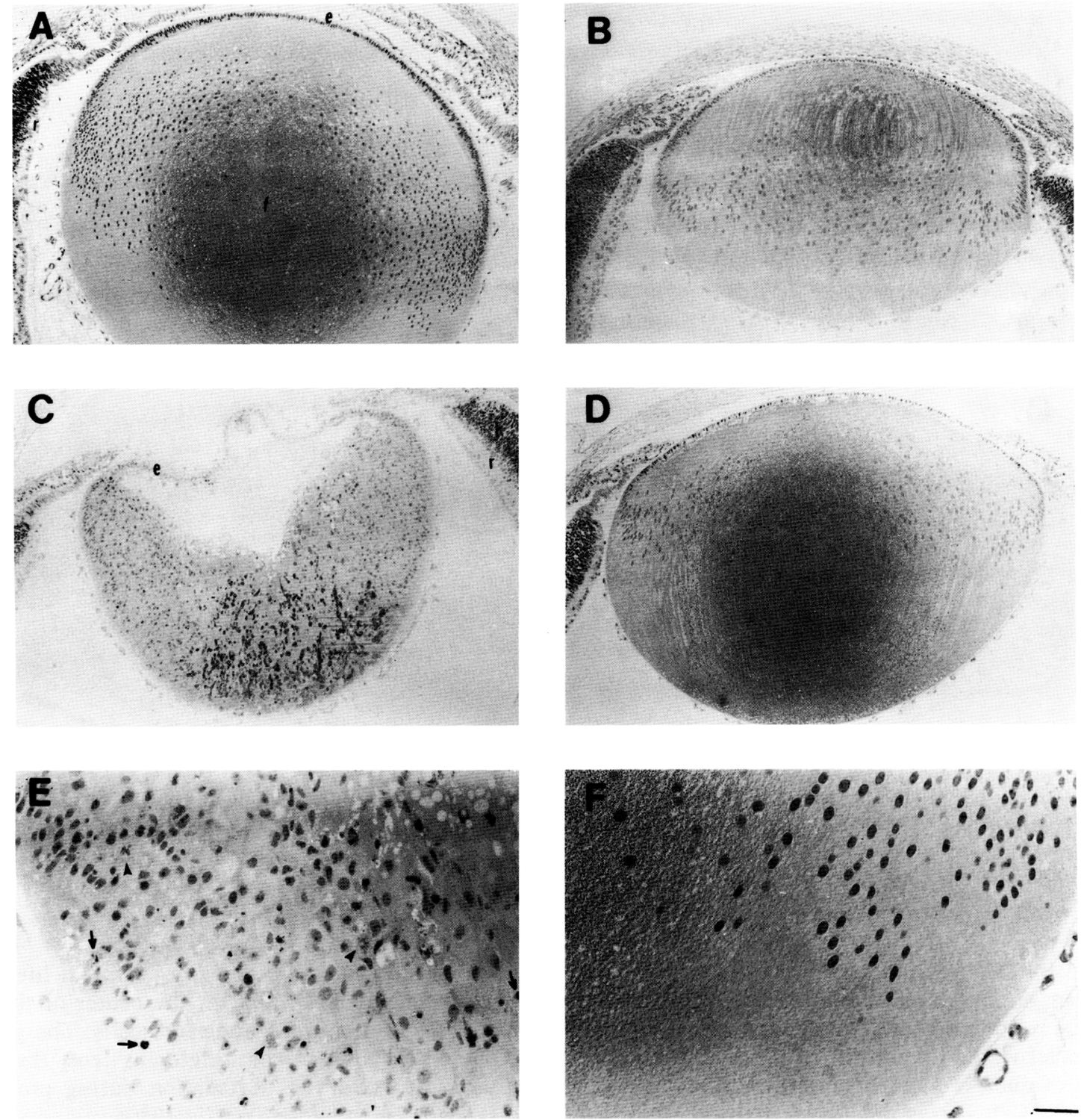

Figure 4. Histology of lenses from nontransgenic FVB/N, $\alpha$ AE6/E7TTL, $\alpha$ AE6TTL/E7, and $\alpha$ AE6TTL/E7Rb ${ }^{-}$neonatal transgenic mice. All eyes were embedded in methacrylate, sectioned at $1.5 \mu \mathrm{m}$, and stained with hematoxylin and eosin. Representative sections are shown. $(A)$ Nontransgenic FVB/N; $(B) \alpha A E 6 / E 7 T T L$ line $384 ;(C) \alpha A E 6 T T L / E 7$ line $75 a_{;}(D) \alpha A E 6 T T L / E 7 R^{-}$line $391 \mathrm{a} ;(E)$ higher magnification of the left posterior region of the $\alpha \mathrm{AE} 6 \mathrm{TTL} / \mathrm{E} 7$ line 75a lens shown in $C_{;}(F)$ higher magnification of the equatorial region of nontrancgenic lens shown in $A$. (e) Epithelial cells; ( $f$ ) fiber cells; ( $r$ ) retina; (arrowhead) mitosis; (arrow) pycnotic or fragmented nucleus. Bar, $11 \mu \mathrm{m}$ for $A-D$ and $3 \mu \mathrm{m}$ for $E$ and $F$. In all panels, the anterior of the lens is oriented at the top.

nostaining paraffin-embedded sections from $\alpha$ AE6TTL/ E7 eyes with a monoclonal antibody against proliferating cell nuclear antigen (PCNA), a protein that is only detectable during late $G_{1}$ and $S$ phase in proliferating cells (Morris and Mathews 1989). A sizable proportion of the total number of cells in the $\alpha$ AE6TTL/E7 lens were PCNA positive (Fig. $6 \mathrm{G}, \mathrm{H}$ ). These PCNA-positive cells were particularly numerous in the posterior region of the lens, where no proliferating cells are found in the nontransgenic lens (Fig. 6E,F). These histological features indicate that the presence of $E 7$ inhibited normal lens fiber cell differentiation, induced cell proliferation in inappropriate regions of the lens, and induced cell death.

The $\alpha A E 6 / E 7 T T L$ lenses The histology of the $\alpha \mathrm{AE} 6 /$ E7TTL lenses was distinct from that of $\alpha$ AE6TTL/E7 mice. Neonatal lenses from $\alpha$ AE6/E7TTL line 384 mice (also reflective of that in mice from line 381, which also exhibited cataracts) exhibited elongated fiber cells, as did lenses from nontransgenic mice; however, fiber cells in the center of the $\alpha \mathrm{AE} 6 / \mathrm{E} 7 \mathrm{TTL}$ lens retained nuclei, whereas the fibers in center of the nontransgenic lens did 

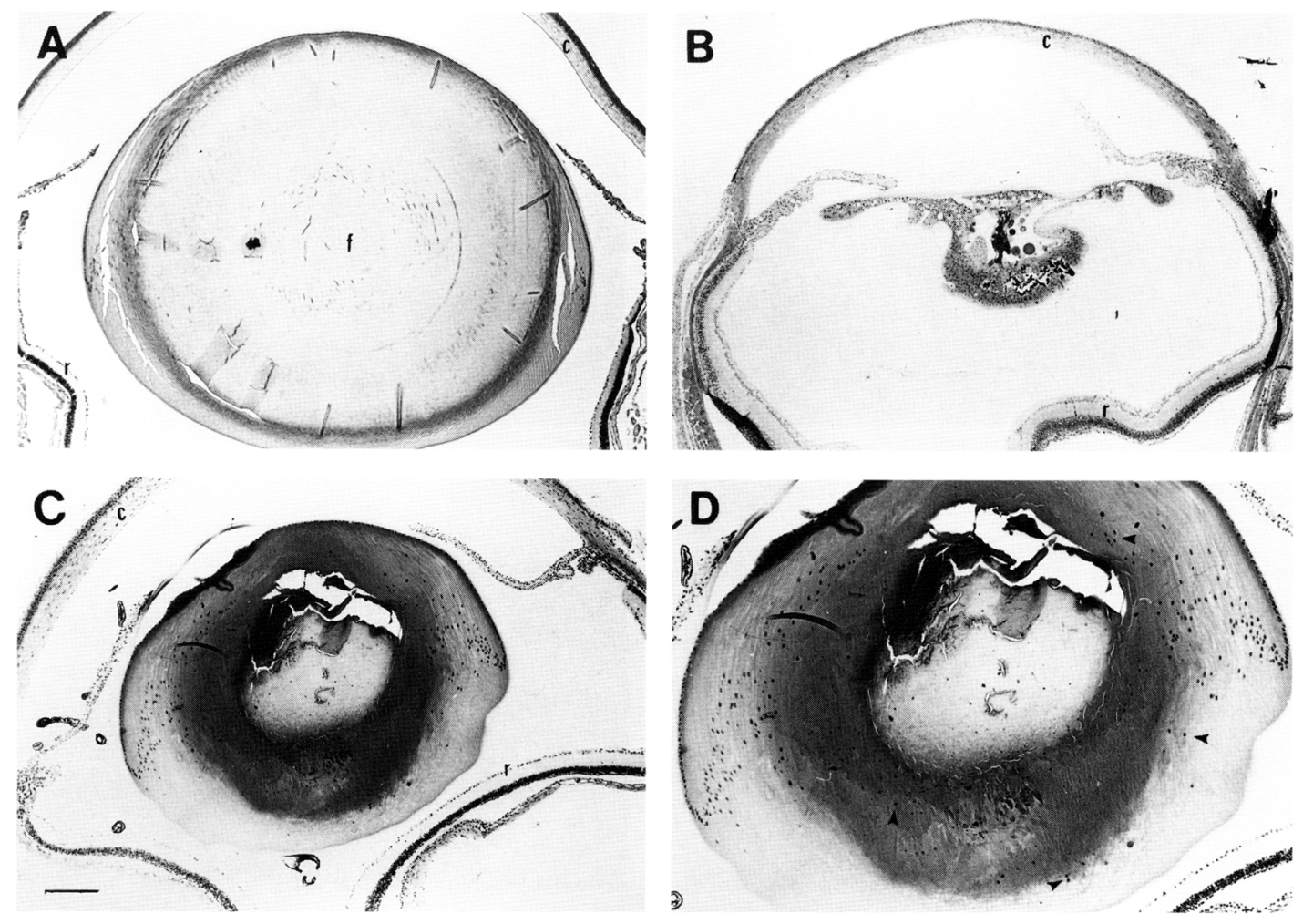

Figure 5. Histology of lenses from FVB, $\alpha$ AE6TTL/E7, and $\alpha$ AE6/E7TTL adult transgenic mice. Eyes were isolated from animals 1-3 months of age, embedded in methacrylate, sectioned at $1.5 \mu \mathrm{m}$, and stained with hematoxylin and eosin. Representative sections are shown. $(A)$ Nontransgenic FVB/N; $(B) \alpha A E 6 T T L / E 7$ line $75 a_{;}(C) \alpha A E 6 / E 7 T T L$ line 384; $(D)$ higher magnification. (c) Cornea; $(e)$ epithelial cells; (f) fiber cells; ( $\mathrm{r}$ ) retina; (arrowhead) mitosis; (arrow) pycnotic or fragmented nucleus. Bar, $22 \mu \mathrm{m}$ for $A-C$ and $11 \mu \mathrm{m}$ for $D$. In all panels, the anterior of the lens is oriented at the top.

not (Fig. 4A,B). The spatial arrangement of nuclei seen in the nontransgenic lens was disrupted in the $\alpha \mathrm{AE} 6 /$ E7TTL lens. In adult $\alpha$ AE6/E7TTL mice, intact and fragmented nuclei were present in fiber cells that normally are devoid of nuclear material (Fig. 5, cf. A, C, and D). The $\alpha$ AE6/E7TTL lenses did not contain any mitotic cells in unusual regions of the lens (Figs. 4B, 5C,D), although some of the nuclei (predominantly at the equatorial region) were PCNA positive (Fig. 6C,D). There was no evidence for induced cell death in the $\alpha$ AE6/E7TTL neonatal lens (Fig. 4, cf. A and B). These results indicate that expression of $\mathrm{E} 6$ in the lens affects the ability of lens fiber cells to undergo denucleation, a process that normally occurs in the differentiation of lens fiber cells.

\section{The effect of E6 on lens DNA degradation}

During normal mouse lens development, at around day 15.5 of embryogenesis, differentiated primary lens fiber cells begin to lose their nuclei (Kuwabara and Imaizumi 1974). The process of fiber cell denucleation in the developing chick (day 15) has been correlated with the initiation of DNA fragmentation. Between days 15 and 21, DNA accumulates as nucleosomal-length pieces (Appleby and Modak 1977). The secondary fibers that continue to form the cortical regions of the lens during late embryogenesis and during early postnatal life also undergo denucleation. By birth, the center of the lens is composed entirely of denucleated cells. The process of DNA degradation in the developing lens, therefore, is reminiscent of DNA degradation during programmed cell death, or apoptosis (Wyllie 1980).

Because of the aberrant retention of nuclei in the fiber cells of $\alpha$ AE6/E7TTL mice, we wished to know whether E6 could inhibit the apoptotic-like breakdown of DNA that is associated with fiber cell denucleation. Total genomic DNA was isolated from lenses of embryos at 15.5 $\mathrm{dpc}$ and neonates. Because of the low level of apoptosis normally found in the developing lens (see Fig. 7B; Appleby and Modak 1977), the genomic DNAs were 3 '-end labeled with $\left[\alpha^{-32}\right.$ P]ddATP using terminal deoxytransferase, fractionated on agarose gels, and analyzed by autoradiography (Fig. 7A). The pattern of DNA degradation observed in the 15.5-dpc nontransgenic lens is similar to that seen during the early stages of lens fiber cell denucleation in the chick (Appleby and Modak 1977) and the early stages of apoptosis in dexamethasone-treated thymocytes (Walker et al. 1993). The DNA degradation in lenses from E6-expressing 15.5-dpc embryos was reduced compared with that seen in lens DNA from nontransgenic 15.5-dpc embryos. Likewise, the degradation seen in the DNA from E6-expressing neonatal lenses was re- 

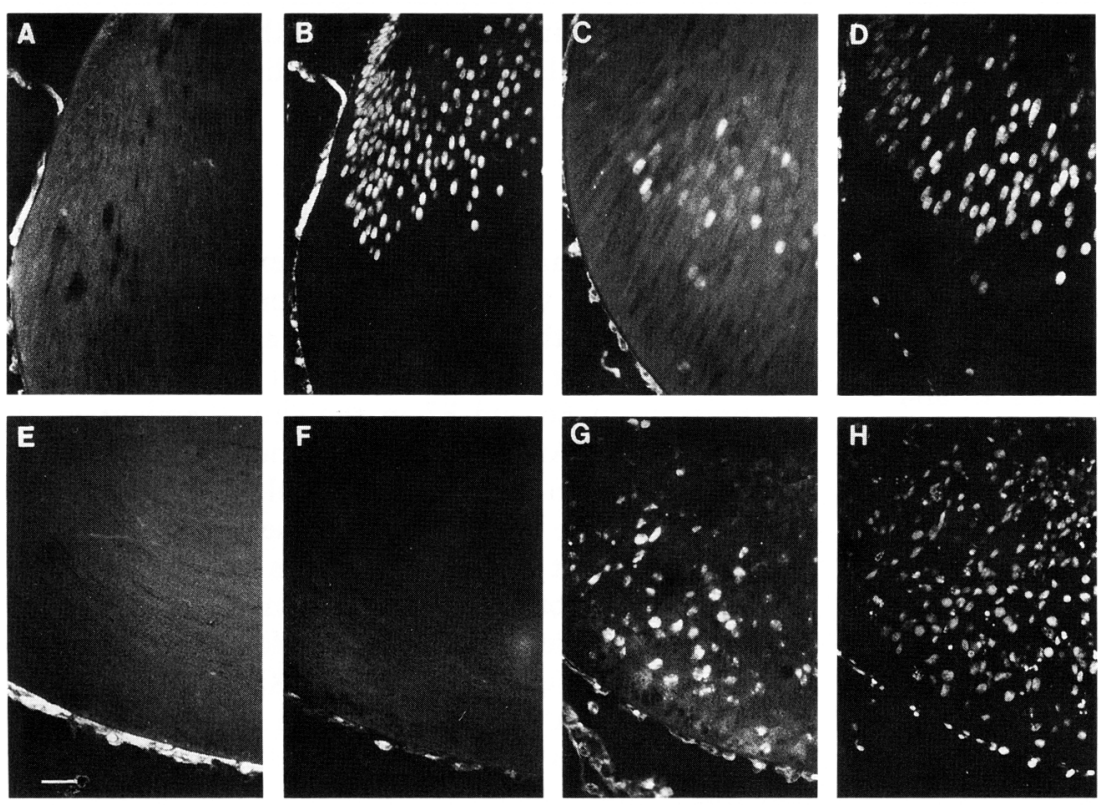

Figure 6. Immunohistochemical analysis of PCNA expression in the lens. Paraffin sections of neonatal eyes from nontransgenic, transgenic aAE6/E7TTL line 384, and transgenic $\alpha$ AE6TTL/E7 line 908 mice were immunostained with mouse anti-human PCNA monoclonal antibody and FITC-conjugated horse anti-mouse IgG secondary antibody. After immunostaining, sections were stained with propidium iodide to stain nuclei. Sections were examined under fluorescein and rhodamine filters. $(A, B)$ Equatorial region from a nontransgenic lens under fluorescein and rhodamine filters, respectively; $(C, D)$ equatorial region from an $\alpha$ AE6/E7TTL line 384 lens under fluorescein and rhodamine filters, respectively; $(E, F)$ left posterior region from nontransgenic lens under fluorescein and rhodamine filters, respectively; $(G, H)$ the left posterior region from an $\alpha$ AE6TTL/ E7 line 908 lens under fluorescein and rhodamine filters, respectively. Bar, $3 \mu \mathrm{m}$. In all panels, the anterior of the lens is oriented at the top. duced compared with that seen in DNA from nontransgenic neonatal lenses (data not shown). Thus, the retention of nuclei in the $\alpha$ AE6/E7TTL lens fibers (Figs. 4 and 5) was correlated with the reduction in the apoptotic-like process noted previously to occur during lens fiber cell denucleation.

\section{The effect of $E 7$ on apoptosis in the lens}

We observed numerous pycnotic and fragmented nuclei in cells of the E7-expressing neonatal lens in areas of the lens not normally containing nucleated cells (Fig. 4). Because these histological features have been correlated previously with apoptosis (Wyllie 1980), we asked whether E7 induced degradation of lens DNA into nucleosomal-length fragments, a diagnostic molecular characteristic of apoptosis (Wyllie 1980). Total genomic DNAs were isolated from neonatal $\alpha$ AE6TTL/E7 and nontransgenic FVB lenses, and electrophoresed on agarose gels. A large abundance of nucleosomal-length fragments was found in transgenic lens DNA from the two different $\alpha$ AE6TTL/E7 lines analyzed, whereas very lit-

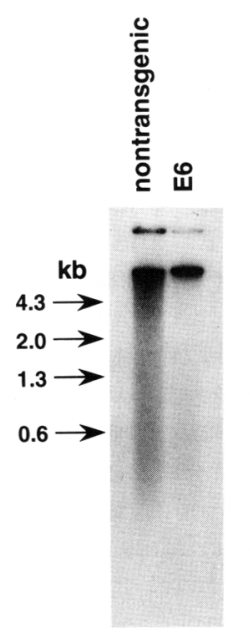

B
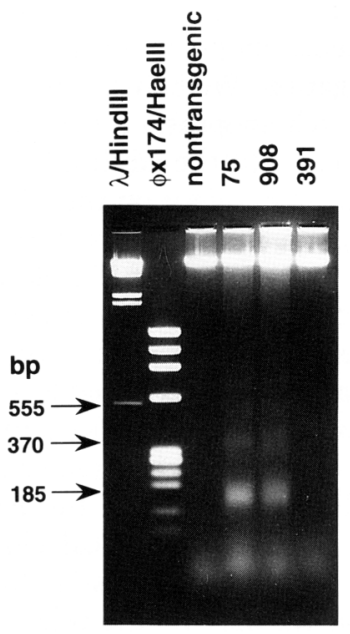

C
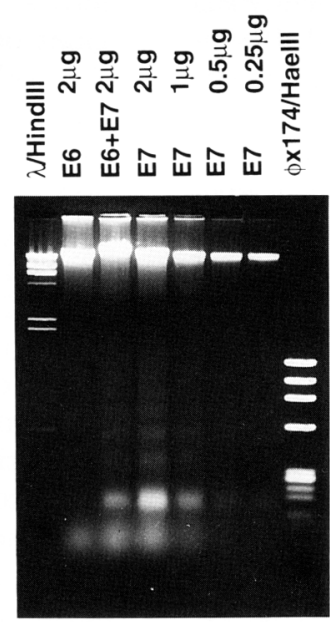

Figure 7. Analysis of apoptosis in the nontransgenic and transgenic lenses. $(A)$ Embryonic (day 15.5) lens DNA from nontransgenic and $\alpha \mathrm{AE} 6 /$ E7TTL line 381 was $3^{\prime}$-end labeled with $\left[\alpha^{-}{ }^{32} \mathrm{P}\right] \mathrm{d}$ dATP using terminal deoxytransferase, fractionated on a $2 \%$ agarose gel, and analyzed by autoradiography. Size markers at left correspond to the positions of $\lambda$ HindIII-digested DNA. $(B)$ Neonatal lens DNA isolated from nontransgenic, $\alpha$ AE6TTL/E7 lines 75a and 908, and $\alpha$ AE6TTL/ $\mathrm{E} 7 \mathrm{Rb}^{-}$line 39la was fractionated on a $2 \%$ agarose gel and stained with ethidium bromide. The sizes of the DNA fragments in samples from line 75 and 908 are indicated at left and correspond to nucleosomal-length monomer, dimer, and trimers. $(C)$ Neonatal lens DNA from $\alpha$ AE6/E7TTL line 384 (E6), the $75 \mathrm{a} \times 381 \mathrm{a}$ double transgenics (E6 +E7), and $\alpha$ AE6TTL/E7 line 75a (E7) was fractionated on a $2 \%$ agarose gel and stained with ethidium bromide. The amount of DNA loaded in

each lane is indicated (top). The amount of low molecular weight DNA in the sample from the double transgenic mice was compared with that in the sample from $\alpha$ AE6TTL/E7 mice only by densitometric scanning of negatives from photographs of ethidium bromidestained agarose gels. For $B$ and $C, \lambda H$ indIII (sizes top to bottom, 23.1, 9.4, 6.6, 4.3, 2.3, 2.0, and $0.6 \mathrm{~kb}$ ) and $\phi \mathrm{X} 174 \mathrm{HaeIII}$ (sizes top to bottom, 1353, 1078, 872, 603, 281/271, 234, 194, and $118 \mathrm{bp})$. 
tle was found in nontransgenic lens DNA (Fig. 7B). These data indicate that E7 expression is associated with induction of apoptosis in lens cells.

\section{The effect of $E 6$ on E7-induced apoptosis}

It is known that the AdE1A oncoprotein can induce apoptosis in tissue culture cells and that the AdE1B protein can inhibit E1A-induced apoptosis (Debbas and White 1993). It was of interest, therefore, to know whether E6 would inhibit the induction of apoptosis of $\mathrm{E} 7$ in the lens in vivo. Mice transgenic for line 75a of $\alpha \mathrm{AE} 6 \mathrm{TTL} / \mathrm{E} 7$ and for line 381a of $\alpha A E 6 / E 7 T T L$ were mated to produce double transgenic neonates from which total genomic lens DNA was prepared. The abundance of nucleosomallength DNA fragments in the DNA from double transgenic mice was compared with lens DNA from aAE6TTL/E7 line 75 a mice on ethidium bromide stained agarose gels (Fig. 7C; see Materials and methods). The DNA from the double transgenic mice contained only one-third as much nucleosomal-length fragments as did the DNA from $\alpha$ AE6TTL/E7 mice. Thus, E6 has the capacity to inhibit E7-induced apoptosis. This inhibition of E7-induced apoptosis by E6 in the neonatal lenses (Fig. $7 \mathrm{C}$ ) was correlated with an increased propensity for such double transgenic mice to develop tumors during adult life (Table 1).

\section{Requirement for the Rb-binding domain of $E 7$}

To examine whether inactivation of $\mathrm{Rb}$ and/or $\mathrm{Rb}$-like protein by E7 is responsible for the observed lens phenotype in $\alpha \mathrm{AE} 6 \mathrm{TTL} / \mathrm{E} 7 \mathrm{mice}$, a 4-amino-acid deletion $(\triangle \mathrm{DLYC})$ in the CRII domain of $\mathrm{E} 7$ was introduced into the $\alpha \mathrm{AE} 6 \mathrm{TTL} / \mathrm{E} 7$ transgene to generate the transgene $\alpha$ AE6TTL/E7Rb ${ }^{-}$(Fig. 2). This mutant E7 has been shown previously to encode a stable protein that is unable to associate with $\mathrm{Rb}$ and $\mathrm{Rb}$-like proteins and is deficient in both cellular transformation and adenovirus E2 transcriptional trans-activation (Munger et al. 1989a; Phelps et al. 1992). Seven transgenic mice were generated with this DNA, and three of them were bred to establish lines 391, 691 and 695 (Table 1). Qualitative RNA PCR analysis indicated that three transgene-specific transcripts were expressed in the lenses of these mice (Fig. 3C); and quantitative RNA PCR analysis of line 391a indicated that the level of expression was comparable with that seen in the $\alpha$ AE6TTL/E7 lines that expressed wild-type E7 (Table 2). In contrast to the $\alpha$ AE6TTL/E7 mice, the $\alpha$ AE6TTL/E7Rb ${ }^{-}$mice exhibited normal eyes. In histological sections there was evidence for lens fiber cell elongation, for appropriate patterns of cell proliferation, with no mitotic (Fig. 4, cf. A,C, and D) or PCNA-positive cells (data not shown) in the interior regions of the lens. Finally, analysis of total genomic lens DNA from the $\alpha$ AE6TTL/E7Rb ${ }^{-}$mice showed no evidence of the increased apoptosis seen in the lens DNA of mice expressing wild-type E7 (Fig. 7B). These results indicate that the $\mathrm{Rb}$-binding domain is re- quired for the ability of E7 to induce cell proliferation and apoptosis in inappropriate regions of the lens, implying that the activities of $\mathrm{Rb}$ and/or Rb-like proteins are necessary for regulating normal cell division in differentiating lens fiber cells.

\section{Discussion}

Previous studies have shown that coexpression of HPV$16 \mathrm{E} 6$ and $\mathrm{E} 7$ in the lens of transgenic mice leads to alterations in epithelial cell growth and differentiation and induces tumor formation (Griep et al. 1993), and that coexpression of E6 and E7 in the skin (Lambert et al. 1993), the brain (Arbeit et al. 1993) and germ cells (Kondoh et al. 1991) in transgenic mice also leads to tumor formation in these tissues. In the present study, we have demonstrated that each oncogene has unique effects on the developing mouse lens, which contribute to the disruption of fiber cell differentiation found in $\alpha \mathrm{AE} 6 / \mathrm{E} 7$ transgenic mice (summarized in Fig. 8). The activities of E6 and E7 may be mediated through their interactions with $\mathrm{p} 53$ and $\mathrm{Rb}$ or $\mathrm{Rb}$-like proteins. In turn, this implies that these tumor suppressor gene products have activities that are essential for regulating normal cell cycle control during lens fiber cell differentiation. Apoptosis is a consequence of failing to maintain normal control. Our work also demonstrates that neither E6 nor E7 alone is sufficient to potentiate efficient lens tumorigenesis in vivo, but together these two oncoproteins confer on the lens an increased capacity for tumor formation, in keeping with previous results from tissue culture studies.

The $E 7 R b$-binding domain is required for the induction of topographically abnormal cell proliferation and apoptosis in the lens

We have found that expression of E7 alone leads to the disruption of normal fiber cell differentiation, resulting in microphthalmia and cataracts. The $\alpha$ AE6TTL/E7 lenses exhibited cell proliferation in inappropriate regions of the lens, apoptosis of lens cells, and a lack of fiber cell elongation. We believe that the massive loss of lens cells through apoptosis results in the microphthalmia that is evident in the adult $\alpha$ AE6TTL/E7 lens. The effects of $E 7$ are dependent on the Rb-binding domain of $\mathrm{E7}$, suggesting that interaction between $\mathrm{E} 7$ and $\mathrm{Rb}$ is necessary for the activity of E7. However, because the $\triangle D L Y C$ mutant that we used in our study likely does not distinguish between $\mathrm{Rb}$ and pl07 or p130 binding, it is possible that any or all may mediate control of proliferation and apoptosis in the lens. Recent evidence from the evaluation of chimeras generated with $\mathrm{Rb}$ null embryonic stem cells indicates that the lenses of these embryos possess similar histological characteristics to our $\alpha$ AE6TTL/E7 transgenic lenses (T. Jacks, pers. comm.), suggesting that $\mathrm{Rb}$ may be the relevant target for $\mathrm{E} 7 \mathrm{in}$ altering lens development. However, it is possible that the action of E7 on Rb-like proteins may also contribute to the observed phenotype. Furthermore, our data do not rule out the possibility that other domains of E7, specif- 


\section{Characteristics}

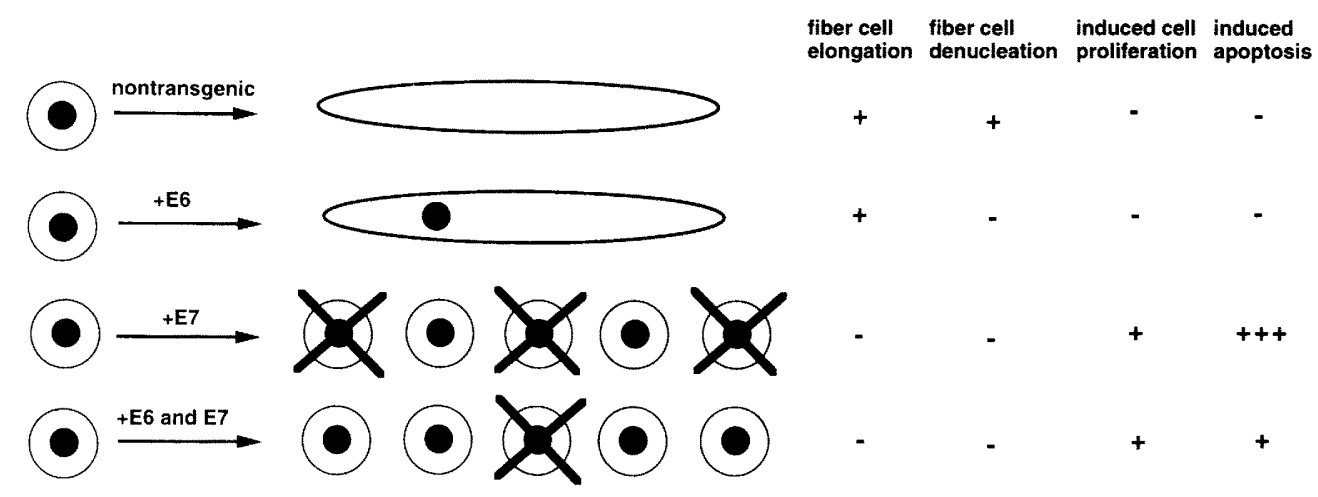

Figure 8. Summary of results. The terminal differentiation of lens fiber cells involves permanent withdrawal from the cell cycle, cell elongation, and denucleation. In the presence of HPV-16 E6, differentiating lens fiber cells fail to denucleate. In the presence of HPV-16

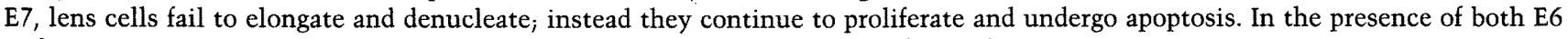
and E7, apoptosis is reduced compared with that observed in the presence of E7 only.

ically the CRI domain, may also confer on this oncoprotein an ability to alter cell growth and differentiation in the lens. The CRI domain has been argued previously to have transformation activity (Jewers et al. 1992; Phelps et al. 1992); however, to date the molecular mechanism for explaining this property has not been elucidated.

It remains an open question as to the mechanism through which inhibiting $\mathrm{Rb}$ and/or p107 disrupts fiber cell differentiation, leading to abnormal cell proliferation and apoptosis in the lens. Inhibiting $\mathrm{Rb} / \mathrm{p} 107$ activity may result in increased activity of the transcription factor E2F, which would be predicted to increase expression of E2F-responsive genes such as c-myc. Increased c-myc expression in a cell that otherwise resides in an environment not supportive for cell proliferation may result in apoptosis. Such is the case when serum is withdrawn from cultures of fibroblasts that express a deregulated c-myc gene (Evan et al. 1992). In the context of a developing organ such as the lens, a lack of specific nutrients or growth factors may exist within certain spatial regions. This absence of an environment supportive of cell growth may force cells that cannot become quiescent, because of the lack of functional $\mathrm{Rb}$, into programmed cell death. It is interesting to note in this context that increases in the steady-state levels of c-myc RNA were observed in $\alpha$ AE6/E7 lenses (A.E. Griep, unpubl.). Another potential target through which E7 might induce apoptosis is p53. Expression of E7 (Demers et al. 1994) or AdE1A (Lowe and Ruley 1993) in tissue culture cells has been associated with increased abundance of p53 protein. The p53 protein has been shown to be required for the induction of apoptosis after treatment of cells with radiation (Clarke et al. 1993; Lowe et al. 1993). That the consequence of a deficit in functional $\mathrm{Rb}$ protein may be an increase in $\mathrm{p} 53$ protein underscores the concept that these tumor suppressor gene products function in an interactive system that controls the cell cycle not only in the undifferentiated cell, which maintains a proliferative capacity, but also in the differentiating cell, which loses that capacity.

\section{E6 inhibits the lens fiber cell denucleation process}

Several results from our study indicate that E6 has distinct effects on the developing lens. When expressed alone in the lens, E6 did not result in microphthalmia or promote cell division in abnormal regions of the neonatal lens, and apparently did not prevent elongation of fiber cells. Nevertheless, cataracts were found in these E6-expressing mice. The occurrence of cataracts in adult mice was correlated with the presence of nuclei in lens fibers of neonatal and adult mice and inhibition of DNA degradation in lenses of 15.5-day embryos. E6 also had the capacity to inhibit E7-induced apoptosis in the lens in double transgenic mice, similar to the ability of AdE1B 55-kD protein, which also binds $\mathrm{p} 53$, to inhibit E1A-induced apoptosis in tissue culture cells (Rao et al. 1992). Finally, in double transgenic mice the ability of E6 to inhibit E7 activity was correlated with potentiation for tumorigenesis, suggesting that inhibition of apoptosis is a necessary component in E6/E7-mediated tumor formation.

One mechanism through which E6 might inhibit the degradation of fiber cell DNA to nucleosomal-length fragments and the loss of cell nuclei is by inhibiting p53 activity. This mechanism would predict that p53 activity is necessary for the denucleation process during lens development. It is interesting that lens fiber cells in $\alpha$ AE6/E7TTL mice contained nuclei that were PCNA positive. Wild type p53 has been shown to inhibit cell growth and down-regulate the PCNA promoter (Mercer et al. 1991; Deb et al. 1992). It is possible that inactivating p53 through E6 binding relieves repression of genes required for cell proliferation such as PCNA, resulting in continued progress through the cell cycle. That mitotically active cells were not observed in the E6 neonatal 
lenses suggests a lack of positive factors or the presence of negative factors affecting cell cycle progression at this particular time in lens development. The consequence of altering cell cycle progression through E6 activity results in disruption of fiber cell differentiation.

However, if $\mathrm{p} 53$ inactivation by $\mathrm{E} 6$ were solely responsible for the phenotype of the $\alpha$ AE6/E7TTL mice, it is curious that no abnormalities have been noted to date in the lenses of p53-deficient mice (Donehower et al. 1992; $\mathrm{T}$. Jacks, pers. comm.). This apparent discrepancy may be attributable to differences in the genetic background of our transgenic mice and the p53 knockout mice. Alternatively, the lack of the cataract phenotype in p53 knockout mice may be attributable to functional compensation for the p53 deficiency, and E6 not only inactivates p53 but also interferes with that mechanism of compensation. Alternatively, it is also possible that activities of E6 genetically distinct from p53 inactivation are responsible for the $\alpha \mathrm{AE} 6 / \mathrm{E} 7 \mathrm{TTL}$ phenotype. In tissue culture systems, the E6 protein has been shown to transcriptionally trans-activate the adenovirus E2 promoter (Sedman et al. 1991; Mietz et al. 1992) and to interface with the ubiquitin system at least in human cells (Scheffner et al. 1990; Huibregtse et al. 1993). It may be one of these, or other undefined E6 activities that are required for the effects of E6 on the lens. Finally, it is possible that $\mathrm{p} 53$ inactivation is necessary but not sufficient for the activity of E6 in inhibiting fiber cell denucleation.

\section{Comparison of individual activities of E6 and E7 with combined activities}

The lenses expressing E7 only / $\alpha$ AE6TTL/E7 transgenic mice) were histologically very similar to the lenses expressing both E6 and E7 $\{\alpha \mathrm{AE} 6 / \mathrm{E} 7$ transgenic mice; Griep et al. 1993), indicating that the major contributor to the $\mathrm{E} 6 / \mathrm{E} 7$ lens phenotype is E7. The ability of E7 to inhibit normal fiber cell elongation and to induce abnormal cell proliferation and apoptosis was dependent on the $\mathrm{Rb}$-binding domain. Thus, the inactivation of $\mathrm{Rb} /$ p107 by E7 is essential for E7's contribution to the E6/E7 phenotype, including lens tumorigenesis. The extent of induced apoptosis appeared to be greater in $\alpha \mathrm{AE} 6 \mathrm{TTL} / \mathrm{E} 7$ lenses than in $\alpha A E 6 T T L / E 7 \times \alpha A E 6 / E 7 T T L$ lenses, and this was correlated with the degree of microphthalmia in these mice. That E6 inhibited the ability of E7 to induce apoptosis (Fig. 7C) suggests that $\mathrm{E} 6$ may be important in the genesis of cancers by HPV-16. Consistent with this hypothesis, 7 of 44 double transgenic mice, generated by breeding line 75a $\alpha \mathrm{AE} 6 \mathrm{TTL} / \mathrm{E} 7$ mice to line 38la $\alpha \mathrm{AE} 6 /$ E7TTL mice, developed a lens tumor by 6-7 months of age, whereas 0 of 47 and 0 of 21 , respectively, developed tumors at ages of 12 months or greater (Table 1). The induction of lens tumors by E6 and E7 recapitulates the observation made previously that one line of $\alpha \mathrm{AE} 6 / \mathrm{E} 7$ mice developed lens tumors (Griep et al. 1993).

\section{$E 6$ and $E 7$ as probes for understanding development}

To study the potential involvement of tumor suppressor gene products in lens development, we used HPV-16 E6 and E7 as trans-dominant repressors of tumor suppressor gene function. The E6 and E7 genes were found to exert unique effects on the development of this tissue, and the effects of E7 were shown to depend on the particular domain of this protein, which is required for interaction with the cellular gene products $\mathrm{Rb}, \mathrm{p} 107$, and $\mathrm{p} 130$. Importantly, disrupting the development of this particular tissue did not result in lethality to the embryo, allowing for evaluation of the long-term effects of interfering with the function of $\mathrm{Rb}$ and/or its related proteins. The sum of the data indicates that the tumor suppressor genes $\mathrm{Rb}$ and $\mathrm{p} 53$ are likely to provide essential functions for regulating cell cycle control during lens development. However, both E6 and E7 are known to possess activities in addition to inactivating $\mathrm{p} 53$ and $\mathrm{Rb}$. Analysis of the behavior of additional mutants in transgenic mice may further extend our understanding of the cellular gene products involved in regulating cell proliferation, differentiation, and apoptosis in the development of the lens.

\section{Materials and methods}

\section{Transgene construction and production of transgenic mice}

The $\alpha$ AE6TTL/E7 and $\alpha$ AE6/E7TTL transgenes were generated by PCR amplification of plasmids p1427 and p1466 (Munger et al. $1989 \mathrm{~b}$ |, respectively, using the BamHI-tailed oligo 1 and oligo 4, as described (Griep et al. 1993). Plasmids pl427 and p1466 contained the HPV-16 E6/E7 sequences with the insertion of a TTL $\left(5^{\prime}\right.$-TTAGTTAACTAA-3') in E6 (nucleotide 158) or E7 (nucleotide 711), respectively (Munger et al. 1989b). The amplified fragment was cloned into the unique $B a m H I$ site, which is downstream of the murine $\alpha \mathrm{A}$ crystallin promoter and upstream of the SV40 polyadenylation sequences in the $\alpha \mathrm{IpA}$ vector derived from pUC18. The resulting plasmids, paIl427 and $\mathrm{p} \alpha \mathrm{I} 1466$, were analyzed by restriction enzyme mapping and sequencing to verify the position of the TTL and the integrity of the $\alpha \mathrm{A}$ crystallin promoter and E6/E7 sequences.

For the construction of $\alpha \mathrm{AE} 6 \mathrm{TTL} / \mathrm{E} 7 \mathrm{Rb}^{-}$, the E6/E7 sequences from plasmid p1467 that contained a deletion of amino acids 21-24, DLYC, in the E7 sequence (Munger et al. 1989a; Phelps et al. 1992) were first subcloned into $\alpha \mathrm{IpA}$ vector as described above. Subsequently, plasmids paI1427 and p $\alpha 1467$ were digested with BsrFI. The fragment from paI1427, which contained $\alpha \mathrm{A}$ crystallin promoter and E6 sequences, was then ligated to the fragment from $\mathrm{p} \alpha \mathrm{I} 1467$, which contained polyadenylation sequences and the E7DDLYC sequences. This construct was also extensively mapped and sequenced to confirm the correct position of the TTL, DLYC deletion, and integrity of the promoter and E6/E7 sequences.

Transgenic mice were generated by microinjecting the purified XmaI-Sall fragments from the transgene constructs into the male pronuclei of one-cell FVB/N embryos as described (Hogan et al. 1986; Griep et al. 1993). Transgenic mice were identified initially by PCR using tail DNA with two primers, $\alpha$ cry3 and oligo 4 , which amplified a transgene-specific fragment $\sim 950$ bp. For Southern blot analyses, $10 \mu \mathrm{g}$ of genomic tail DNA was digested routinely with BamHI, electrophoresed on $0.8 \%$ agarose gel, transferred on nitrocellulose membrane, and then hybridized with an E6/E7-specific probe that was radiolabeled using the random primed labeling kit from Boehringer Mannheim (Indianapolis, IN). For copy number analysis, $10 \mu \mathrm{g}$ of tail DNA was digested with EcoRI and subjected to Southern 
hybridization with an $\alpha \mathrm{A}$ crystallin promoter-specific probe. This probe identified a band corresponding to the endogenous $\alpha \mathrm{A}$ crystallin gene as well as a unit-length band corresponding to the transgene. Because $\alpha \mathrm{A}$ crystallin is a single copy gene in the mouse genome (per haploid), the copy number of the transgene was assessed by quantifying and comparing the intensity of the transgene band to the endogenous $\alpha \mathrm{A}$ crystallin band.

\section{Expression studies by RNA PCR}

Total RNA was prepared from neonatal lenses as described (Griep et al. 1993). RNA (4 $\mu \mathrm{g}$ ) from various lineages were used routinely for qualitative analysis. First, RNA was pretreated with RNase-free DNase; half of the sample $(2 \mu \mathrm{g})$ was then subjected to RNase digestion to serve as a negative control. After completion of the enzyme digestion, both samples were phenol-chloroform extracted and ethanol precipitated. For $\mathrm{Rb}$ and $\mathrm{p} 53$ expression, RNAs were reverse-transcribed with $\mathrm{Rb}-2$ (complementary to nucleotides 1476-1452 of mouse $\mathrm{Rb}$ ) and p53-4 (complementary to nucleotides $642-619$ of mouse p53), respectively, and subsequently amplified by PCR with Rb-1 (nucleotides 1152-1172) and Rb-2, and p53-1 (nucleotides 287-306) and p53-4. For transgene expression, the RNAs were reversetranscribed with oligo 2 using Moloney murine leukemia virus (MMLV) reverse transcriptase (Bethesda Research Laboratories, Bethesda, MD|, and the resulting cDNAs were PCR-amplified with oligo 2 and $\alpha \mathrm{pl}$, as described (Griep et al. 1993). The PCR products were resolved on $2 \%$ agarose gels and further confirmed by Southern hybridization to the radiolabeled E6/E7 DNA probe. Quantitative RNA PCR was performed as described (Griep et al. 1993). For generation of standards for quantification of product, E7-specific RNA was transcribed in vitro by using SP6 polymerase, and the amount of SP6 RNA was quantified on agarose gels. cDNA was then generated by reverse transcription of a specific amount of SP6 RNA by using oligo 4 above, and serial dilutions of the cDNA /corresponding to $0.1 \times 10^{5}$ to $1 \times 10^{5}$ molecules of E7-specific RNA/ were PCR amplified with oligos 3 and 4 (see Fig. 2). PCR mixtures were run in triplicate for each serial dilution of standards and lens samples within an experiment, and the experiments were repeated three times each. The amount of radioactive product was quantified by PhosphorImager (Molecular Dynamics, Sunnyvale, CA).

\section{Histological and immunohistochemical analysis}

Neonatal and adult eyes isolated from various lines of mice were fixed in $4 \%$ paraformaldehyde overnight at $4^{\circ} \mathrm{C}$, transferred to phosphate-buffered saline, dehydrated in increasing concentrations of ethanol, and embedded in methacrylate (JB-4 embedding kit; Polysciences, Inc. Warrington, PA). Sections (1.5 $\mu \mathrm{m}$ ) were cut on an ultramicrotome and stained with hematoxylin and eosin. For immunohistochemistry, paraformaldehydefixed eyes were embedded in paraffin, and serial sections of 5 $\mu \mathrm{m}$ thickness were cut. The paraffin sections were incubated overnight at $37 \cdot \mathrm{C}$, then deparaffinized, rehydrated, and incubated with mouse anti-human PCNA monoclonal antibody (Boehringer Mannheim, Indianaoplis, IN; 1:20 dilution) overnight at $4^{\circ} \mathrm{C}$. Subsequently, the sections were washed and incubated with fluorescein isothiocyanate (FITC)-conjugated horse anti-mouse IgG secondary antibody (1:200 dilution) in the dark for $1 \mathrm{hr}$. After final wash, the sections were examined by fluorescence microscopy. The sections were further stained with $0.02 \mu \mathrm{g} / \mathrm{ml}$ of propidium iodide for $1 \mathrm{~min}$ and examined under a rhodamine filter to visualize the nuclei.

\section{Isolation of lens DNA and apoptosis analysis}

Lenses were isolated from neonates or day 15.5 embryos and immediately frozen on dry ice. Embryos were staged by designating midday on the day of the vaginal plug as day 0.5 of development. Total genomic DNA was prepared by the procedure adapted from Gross-Bellard et al. (1973) with modifications. Briefly, lenses were incubated with $1.5 \mathrm{ml}$ of genomic lysis buffer [ $20 \mathrm{~mm}$ Tris-Cl (pH 8.0), $150 \mathrm{~mm} \mathrm{NaCl}, 100 \mathrm{~mm}$ EDTA $(\mathrm{pH} 8.0), 1 \%$ SDS, plus $25 \mu \mathrm{l}$ of $\beta$-mercaptoethanol, and $7.5 \mu \mathrm{l}$ of $20 \mathrm{mg} / \mathrm{ml}$ proteinase $\mathrm{K} /$ at $37^{\circ} \mathrm{C}$ with severe shaking for $4 \mathrm{hr}$. This solution was extracted with an equal volume of phenol, followed by re-extraction with an equal volume of phenol-chloroform twice. The supernatant was precipitated by ethanol, and the coiled-out DNA was picked up and resuspended in water. This is the high-molecular weight DNA. The rest of the ethanol solution was frozen in $-20^{\circ} \mathrm{C}$ overnight and centrifuged to precipitate the low molecular DNA. The pellet was resuspended and RNase treated at $37^{\circ} \mathrm{C}$ for $1 \mathrm{hr}$. After final phenol-chloroform extraction and ethanol precipitation, the pellet was resuspended (low-molecular weight DNA), combined with the highmolecular weight DNA, and quantified by absorbance at 260 nm.

To resolve the nucleosomal-length DNA fragments generated by apoptosis, $2 \mu \mathrm{g}$ of the lens DNA was analyzed on $2 \%$ agarose gels and stained with ethidium bromide. The negatives of three independent gels were then scanned using a densitometer and the data averaged. For embryonic lens DNA, $500 \mathrm{ng}$ of the lens DNA was $3^{\prime}$-end labeled with $\left[\alpha^{-32} \mathrm{P}\right]$ ddATP using terminal deoxytransferase (Boehringer Mannheim, Indianapolis, IN) as described (Tilly and Hsueh 1993). The labeled DNA was separated on $2 \%$ agarose gels, which were then dried and subjected to autoradiography.

\section{Acknowledgments}

We thank William Phelps and Karl Munger for kindly providing the plasmids p1427, p1466, and p1467. We thank Renee Herber and Paul Lambert for generating the plasmids paI1427 and paIl466, and Kathy Helmuth and Jan Lohse of the University of Wisconsin Biotechnology Center's Transgenic Animal Facility for generating the transgenic mice used in this study. We thank Karl Munger and Tyler Jacks for sharing unpublished data, and Paul Lambert for the many insightful discussions concerning this project. We thank Karen Downs and Paul Lambert for editorial comment and Tom Pienkowski for assistance with preparation of the figures. This work was supported in part by U.S. Public Health Service grants P30-CA07175, P01-CA22443, and R01-EY09091 and funds from the University of Wisconsin Medical School and Graduate School.

The publication costs of this article were defrayed in part by payment of page charges. This article must therefore be hereby marked "advertisement" in accordance with 18 USC section 1734 solely to indicate this fact.

\section{References}

Appleby, D.W. and S.P. Modak. 1977. DNA degradation in terminally differentiating lens fiber cells from chick embryos. Proc. Natl. Acad. Sci. 74: 5579-5583.

Arbeit, J.M., K. Munger, P.M. Howley, and D. Hanahan. 1993. Neuroepithelial carcinomas in mice transgenic with human papillomavirus type 16 E6/E7 ORFs. Am. I. Pathol. 142: 1187-1197.

Banks, L., C. Edmonds, and K.H. Vousden. 1990. Ability of the 
HPV16 E7 protein to bind RB and induce DNA synthesis is not sufficient for efficient transforming activity in NIH3T3 cells. Oncogene 5: 1383-1389.

Bernards, R., G.M. Schackleford, M.R. Gerber, J.M. Horowitz, S.H. Friend, M. Schartl, E. Bogenmann, J.M. Rapaport, T. McGee, T.P. Dryja, and R.A. Weinberg. 1989. Structure and expression of the murine retinoblastoma gene and characterization of its encoded protein. Proc. Nat1. Acad. Sci. 86: 6474-6478.

Buchkovich, K., L.A. Duffy, and E. Harlow. 1989. The retinoblastoma protein is phosphorylated during specific phases of the cell cycle. Cell 58: 1097-1105.

Chellappan, S.P., S. Hiebert, M. Mudryj, J.M. Horowitz, and J.R. Nevins. 1991. The E2F transcription factor is a cellular target for the Rb protein. Cell 65: 1053-1061.

Chellappan, S., V.B. Kraus, B. Kroger, K. Munger, P.M. Howley, W.C. Phelps, and J.R. Nevins. 1992. Adenovirus ElA, simian virus 40 tumor antigen, and human papillomavirus E7 protein share the capacity to disrupt the interaction between transcription factor E2F and the retinoblastoma gene product. Proc. Natl. Acad. Sci. 89: 4549-4553.

Chen, P.L., P. Scully, J.-Y. Shew, P. Wang, and W.-H. Lee. 1989. Phosphorylation of the retinoblastoma gene product is modulated during the cell cycle and cellular differentiation. Cell 58: 1193-1198.

Chittenden, T., D.M. Livingston, and W.G. Kaelin Jr. 1991. The $T / E$ lA-binding domain of the retinoblastoma product can interact selectively with a sequence specific DNA-binding protein. Cell 65: 1073-1082.

Clarke, A.R., E.R. Mandag, M. van Roon, N.M.T. van der Lugt, M. van der Valk, M.L. Hooper, A. Berns, and H. te Riele. 1992. Requirement for a functional Rb-1 gene in murine development. Nature 359: 328-330.

Clarke, A.R., C.A. Purdie, D.J. Harrison, R.G. Morris, C.C. Bird, M.L. Hooper, and A.H. Wyllie. 1993. Thymocyte apoptosis induced by p53-dependent and independent pathways. $\mathrm{Na}$ ture 362: 849-852.

Davies, R., R. Hicks, T. Crook, J. Morris, and K. Vousden. 1993. Human papillomavirus type $16 \mathrm{E} 7$ associates with a histone $\mathrm{H} 1$ kinase and with p107 through sequences necessary for transformation. /. Virol. 67: 2521-2528.

Deb, S., C.T. Jackson, M.A. Subler, and W. Martin. 1992. Modulation of cellular and viral promoters by mutant human $\mathrm{p} 53$ proteins found in tumor cells. J. Virol. 66: 6164-6170.

Debbas, M. and E. White. 1993. Wild-type p53 mediates apoptosis by E1A, which is inhibited by E1B. Genes \& Dev. 7: 546-554.

DeCaprio, J.A., J.W. Ludlow, J. Figge, J.-Y. Shew, C.-M. Huang, W.-H. Lee, E. Marsilio, E. Paucha, and D.M. Livingston. 1988. SV40 large tumor antigen forms a specific complex with the product of the retinoblastoma susceptibility gene. Cell 54: 275-283.

DeCaprio, J.A., J.W. Ludlow, D. Lynch, Y. Furukawa, J. Griffin, H. Piwnica-Worms, C.-M. Huang, and D.M. Livingston. 1989. The product of the retinoblastoma susceptibility gene has properties of a cell cycle regulatory element. Cell 58: 1085-1095.

Demers, G.W., C.L. Halbert, and D.A. Galloway. 1994. Elevated wild-type p53 protein levels in human epithelial cell lines immortalized by the human papillomavirus type $16 \mathrm{E} 7$ gene. Virology 198: 169-174.

Donehower, L.A., M. Harvey, B.L. Slagle, M.J. McArthur, C.A. Montgomery Jr., J.S. Butel, and A. Bradley. 1992. Mice deficient for p53 are developmentally normal but susceptible to spontaneous tumors. Nature 356: 215-221.

Dyson, N., P.M. Howley, K. Munger, and E. Harlow. 1989. The human papilloma virus-16 E7 oncoprotein is able to bind to the retinoblastoma gene product. Science 243: 934-937.

Dyson, N., R. Bernards, S.H. Friend, L.R. Gooding, J.A. Hassell, E.O. Major, J.M. Pipas, T. Van Dyke, and E. Harlow. 1990. Large $\mathrm{T}$ antigens of many polyomaviruses are able to form complexes with the retinoblastoma protein. I. Virol. 64: 1353-1356.

Dyson, N., P. Guida, K. Munger, and E. Harlow. 1992. Homologous sequences in adenovirus E1A and human papillomavirus $E 7$ proteins mediate interaction with the same set of cellular proteins. I. Virol. 66: 6893-6902.

El-Deiry, W.S., T. Tokino, V.E. Velculescu, D.B. Levy, R. Parsons, J.M. Trent, D. Lin, W.E. Mercer, K.W. Kinzler, and B. Vogelstein. 1993. WAF1, a potential mediator of p53 tumor suppression. Cell 75: 817-825.

Evan, G.I., A.H. Wyllie, C.S. Gilbert, T.D. Littlewood, H. Land, M. Brooks, C.M. Waters, L.Z. Penn, and D.C. Hancock. 1992. Induction of apoptosis in fibroblasts by c-myc protein. Cell 69: 119-128.

Goodrich, D.W., N.P. Wang, Y.-W. Qian, E.Y.-H.P. Lee, and W.H. Lee. 1991. The retinoblastoma gene product regulates progression through the G1 phase of the cell cycle. Cell 67: 293-302.

Griep, A.E., T. Kuwabara, E.J. Lee, and H. Westphal. 1989. Perturbed development of the mouse lens by polyomavirus large $\mathrm{T}$ antigen does not lead to tumor formation. Genes \& Dev. 3: $1075-1085$.

Griep, A.E., R. Herber, S. Jeon, J.K. Lohse, R.R. Dubielzig, and P.F. Lambert. 1993. Tumorigenicity by human papillomavirus type 16 E6 and E7 in transgenic mice correlates with alterations in epithelial cell growth and differentiation. $J$. Virol. 67: 1373-1384.

Gross-Bellard, M., P. Oudet, and P. Chambon. 1973. Isolation of high-molecular-weight DNA from mammalian cells. Eur. $J$. Biochem. 36: 32-38.

Harper, J.W., G.R. Adami, N. Wei, K. Keyomarsi, and S.J. Elledge. 1993. The p2l Cdk-interacting protein $\mathrm{Cip} 1$ is a potent inhibitor of G1 cyclin-dependent kinase. Cell 75: 805-816.

Hawley-Nelson, P., K.H. Vousden, N.L. Hubbert, D.R. Lowy, and J.T. Schiller. 1989. HPV-16 E6 and E7 proteins cooperate ito immortalize human foreskin keratinocytes. $E M B O$ J. 8: 3905-3910.

Hogan, B., F. Costantini, and E. Lacy. 1986. Manipulating the mouse embryo: A laboratory manual. Cold Spring Harbor Laboratory, Cold Spring Harbor, New York.

Hudson, J.B., M.A. Bedell, D.J. McCance, and L.A. Laimins. 1990. Immortalization and altered differentiation of human keratinocytes in vitro by the $\mathrm{E} 6$ and $\mathrm{E} 7$ open reading frames of human papillomavirus type 18. J. Virol. 64: 519-574.

Huibregtse, J.M., M. Scheffner, and P.M. Howley. 1993. Cloning and expression of the cDNA for E6-AP, a protein that mediates the interaction of the human papillomavirus $\mathrm{E} 6$ oncoprotein with p53. Mol. Cell. Biol. 13: 775-784.

Jacks, T., A. Fazeli, E.M. Schmitt, R.T. Bronson, M.A. Goodell, and R.A. Weinberg. 1992. Effects of an Rb mutation in the mouse. Nature 359: 295-300.

Jewers, R.L., P. Hildebrandt, J.W. Ludlow, B. Kell, and D.J. McCance. 1992. Regions of human papillomavirus type 16 E7 oncoprotein required for immortalization of human keratinocytes. I. Virol. 66: 1329-1335.

Kondoh, G., Y. Murata, K. Aozasa, M. Yutsudo, and A. Hakura. 1991. Very high incidence of germ cell tumorigenesis (seminomagenesis) in human papillomavirus type 16 transgenic mice. I. Virol. 65: 3335-3339.

Kuwabara, T. and M. Imaizumi. 1974. Denucleation process of 
the lens. Invest. Ophthalmol. 13: 973-981.

Lambert, P.F., H. Pan, H.C. Pitot, A. Liem, M. Jackson, and A.E. Griep. 1993. Epidermal cancer associated with expression of human papillomavirus type 16 E6 and E7 oncogenes in the skin of transgenic mice. Proc. Natl. Acad. Sci. 90: 55835587.

Lane, D.P. and L.V. Crawford. 1979. T antigen is bound to a host protein in SV40 transformed cells. Nature 278: 261-263.

Lee, E.Y.-H.P., C.-Y. Chang, N. Hu, Y.-C.J. Wang, C.-C.Lai, K. Herrup, W.-H. Lee, and A. Bradley. 1992. Mice deficient for $\mathrm{Rb}$ are nonviable and show defects in neurogenesis and haematopoiesis. Nature 359: 288-294.

Linzer, D. and A.J. Levine. 1979. Characterization of a $54 \mathrm{kd}$ cellular SV40 tumor antigen present in SV40-transformed cells and uninfected embryonal carcinoma cells. Cell 17: 43-52.

Lowe, S.W. and H.E. Ruley. 1993. Stabilization of the p53 tumor suppressor is induced by adenovirus $5 \mathrm{E} 1 \mathrm{~A}$ and accompanies apoptosis. Genes \& Dev. 7: 535-545.

Lowe, S.W., E.M. Schmitt, S.W. Smith, B.A. Osborne, and T. Jacks. 1993. p53 is required for radiation-induced apoptosis in mouse thymocytes. Nature 362: 847-849.

Mahon, K.A., A.B. Chepelinsky, J.S. Khillan, P.A. Overbeek, J. Piatigorsky, and H. Westphal. 1987. Oncogenesis of the lens in transgenic mice. Science 235: 1622-1628.

Matlashewski, G., J. Schneider, L. Banks, N. Jones, A. Murray, and L. Crawford. 1987. Human papillomavirus type 16 DNA cooperates with activated ras in transforming primary cells. EMBO I. 6: 1741-1746.

McAvoy, J.W. 1978. Cell division, cell elongation and the coordination of crystallin gene expression during lens morphogenesis in the rat. J. Embryol. Exp. Morph. 45: 271-281.

Mercer, W.E., M.T. Shields, D. Lin, E. Appella, and S.J. Ullrich. 1991. Growth suppression induced by wild-type p53 protein is accompanied by selective down-regulation of proliferating-cell nuclear antigen expression. Proc. Natl. Acad. Sci. 88: 1958-1962.

Mietz, J.A., T. Unger, J.M. Huibregtse, and P.M. Howley. 1992. The transcriptional transactivation function of the wild type p53 is inhibited by SV40 large T antigen and by HPV-16 E6 oncoprotein. EMBO J. 11: 5013-5020.

Morris, G.F. and M.B. Mathews. 1989. Regulation of proliferating cell nuclear antigen during the cell cycle. J. Biol. Chem. 264: $13856-13864$.

Munger, K., B.A. Werness, N. Dyson, W.C. Phelps, E. Harlow, and P.M. Howley. 1989a. Complex formation of human papillomavirus $\mathrm{E} 7$ proteins with the retinoblastoma tumor suppressor gene product. EMBO J. 8: 4099-4105.

Munger, K., W.C. Phelps, V. Bubb, P.M. Howley, and R. Schlegel. 1989b. The E6 and E7 genes of the human papillomavirus type 16 together are necessary and sufficient for transformation of primary human keratinocytes. J. Virol. 63: 4417-4421.

Nevins, J.R. 1992. E2F: A link between the Rb tumor suppressor protein and viral oncoproteins. Science 258: 424-429.

Noda, A., Y. Ning, S.F. Venable, O.M. Perreira-Smith, and J.R. Smith. 1994. Cloning of senecent cell-derived inhibitors of DNA synthesis using an expression screen. Exp. Cell Res. 211: 90-98.

Phelps, W.C. and P.M. Howley. 1987. Transcriptional transactivation by the human papillomavirus type $16 \mathrm{E} 2$ gene product. J. Virol. 61: 1630-1638.

Phelps, W.C., C.L. Yee, K. Munger, and P.M. Howley. 1988. The human papillomavirus type 16 E7 gene endcodes transactivation and transformation functions similar to those of adenovirus E1A. Cell 53: 539-547.
Phelps, W.C., K. Munger, C.L. Yee, J.A. Barnes, and P.M. Howley. 1992. Structure-function analysis of the human papillomavirus type 16 E7 oncoprotein. J. Virol. 66: 2418-2427.

Rao, L., M. Debbas, P.Sabbatinin, D. Hockenbery, S. Korsmeyer, and E. White. 1992. The adenovirus E1A proteins induce apoptosis which is inhibited by the E1B $19 \mathrm{~K}$ and Bcl-2 proteins. Proc. Natl. Acad. Sci. 89: 7742-7746.

Rogel, A., M. Popliker, C.G. Webb, and M. Oren. 1985. p53 cellular tumor antigen: Analysis of mRNA levels in normal adult tissues, embryos, and tumors. Mol. Cell. Biol. 5: 28512855.

Sarnow, P., Y.S. Ho, J. Williams, and A.J. Levine. 1982. Adenovirus E1B-58 kd tumor antigen and SV40 T antigen are physically associated with the same $54 \mathrm{kd}$ cellular protein in transformed cells. Cell 28: 387-394.

Scheffner, M., B.A. Werness, J.M. Huibregtse, A.J. Levine, and P.M. Howley. 1990. The E6 oncoprotein encoded by human papillomavirus types 16 and 18 promotes the degradation of p53. Cell 63: 1129-1136.

Schmid, P., A. Lorenz, H. Hameister, and M. Montenarh. 1991. Expression of p53 during mouse embryogenesis. Development 113: 857-865.

Sedman, S.A., M.S. Barbosa, W.C. Vass, N.L. Hubbert, I.A. Haas, D.R. Lowy, and J.T. Schiller. 1991. The full length E6 protein of HPV-16 has transforming and transactivating activities and cooperates with $\mathrm{E} 7$ to immortalize keratinocytes in culture. J. Virol. 65: 4860-4866.

Sedman, S.A., N.L. Hubbert, W.C. Vass, D.R. Lowy, and J.T. Schiller. 1992. Mutant p53 can substitute for human papillomavirus type 16 E6 in immortalization of human keratinocytes but does not have E6-associated trans-activation or transforming activity. J. Virol. 66: 4201-4208.

Storey, A. and L. Banks. 1993. Human papillomavirus type 16 E6 gene cooperates with EJ-ras to immortalize primary mouse cells. Oncogene 8: 919-924.

Storey, A., D. Pim, A. Murray, K. Osborn, L. Banks, and L. Crawford. 1988. Comparison of the in vitro transforming activities of human papillomavirus types. EMBO I. 7: 18151820.

Tilly, J.L. and A.J.W. Hsueh. 1993. Microscale autoradiographic method for the qualitative and quantitative analysis of apoptotic DNA fragmentation. I. Cell. Physiol. 154: 519-526.

Walker, P.R., L. Kokileva, J. LeBlanc, and M. Sikorska. 1993. Detection of the initial stages of DNA fragmentation in apoptosis. BioTechniques 15: 1032-1040.

Werness, B.A., A.J. Levine, and P.M. Howley. 1990. Association of human papillomavirus types 16 and $18 \mathrm{E} 6$ proteins with p53. Science 248: 76-79.

Whyte, P., K.J. Buchkovich, J.M. Horowitz, S.H. Friend, M. Raybuck, R. Weinberg, and E. Harlow. 1988. Association between an oncogene and an anti-oncogene: The adenovirus Ela proteins bind to the retinoblastoma gene product. $\mathrm{Na}$ ture 334: 124-129.

Woodworth, C.D., S. Waggoner, W. Barnes, M.H. Stoler, and J.A. DiPaolo. 1990. Human cervical and foreskin epithelial cells immortalized by human papillomavirus DNAs exhibit dysplastic differentiation in vivo. Cancer Res. 50: 3709-3715.

Wyllie, A.H. 1980. Glucocorticoid-induced thymocyte apoptosis is associated with endonuclease activation. Nature 284: 555-556.

Xiong, Y., G.J. Hannon, H. Zhang, D. Casso, R. Kobayashi, and D. Beach. 1993. p21 is a universal inhibitor of cyclin kinases. Nature 366: 701-704.

Yew, P.R. and A.J. Berk. 1992. Inhibition of p53 transactivation required for transformation by adenovirus early $1 \mathrm{~B}$ protein. Nature 357: 82-85. 


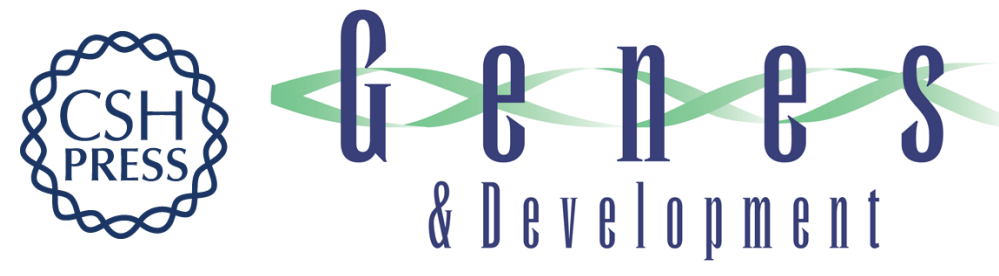

\section{Altered cell cycle regulation in the lens of HPV-16 E6 or E7 transgenic mice: implications for tumor suppressor gene function in development.}

H Pan and A E Griep

Genes Dev. 1994, 8:

Access the most recent version at doi:10.1101/gad.8.11.1285

References This article cites 71 articles, 32 of which can be accessed free at:

http://genesdev.cshlp.org/content/8/11/1285.full.html\#ref-list-1

License

Email Alerting Service

Receive free email alerts when new articles cite this article - sign up in the box at the top right corner of the article or click here.

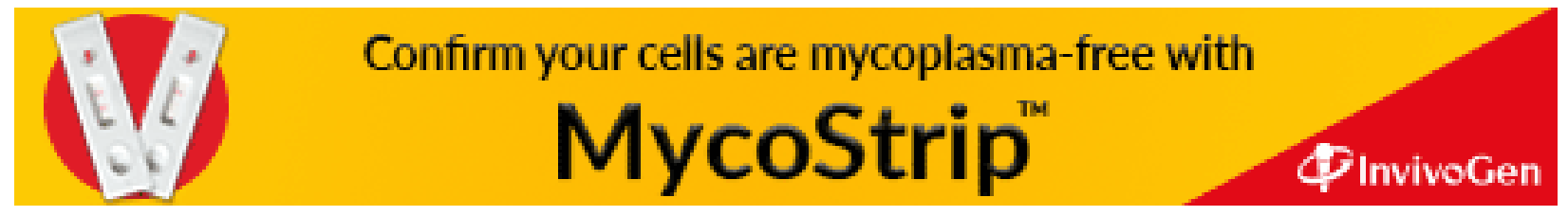

